\title{
Perinatal selective serotonin reuptake inhibitor medication (SSRI) effects on social behaviors, neurodevelopment and the epigenome
}

Mary Gemmel $^{\mathrm{a}}$, Eszter Bögi ${ }^{\mathrm{b}}$, Christina Ragan ${ }^{\mathrm{c}}$, Mariah Hazlett ${ }^{\mathrm{a}}$, Michal Dubovicky ${ }^{\mathrm{b}}$, Daniel L. van den Hove $\mathrm{d}^{\mathrm{d}, \mathrm{e}}$, Tim F. Oberlander ${ }^{\mathrm{f}}$, Thierry D. Charlier ${ }^{\mathrm{g}}$ and Jodi L. Pawluski ${ }^{\mathrm{g}^{*}}$

a'Department of Biological Sciences, Ohio University, Athens, Ohio, USA

${ }^{\mathrm{b}}$ Institute of Experimental Pharmacology and Toxicology, Slovak Academy of Sciences, Bratislava, Slovakia.

cDepartment of Psychology, Colgate University, Hamilton, NY, USA.

${ }^{\mathrm{d}}$ Department of Psychiatry and Neuropsychology, Maastricht University, Maastricht, The Netherlands.

e Division of Molecular Psychiatry, Laboratory of Translational Neuroscience, Center of Mental Health, University of Wuerzburg, Wuerzburg, Germany.

${ }^{\mathrm{f}}$ Department of Pediatrics, University of British Columbia, B.C. Children's and Women's Hospitals, BC Children's Hospital Research Institute, Vancouver, Canada.

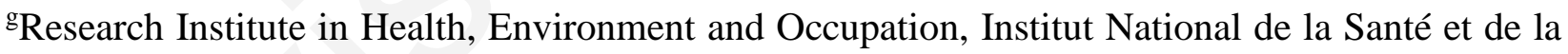
Recherche Médicale U1085, Université de Rennes 1, Rennes, France.

*Corresponding Author: Jodi L. Pawluski, Ph.D., IRSET-INSERM UMR1085, Université de Rennes 1, Campus Villejean, 9 avenue du Prof. Leon Bernard, 35000 Rennes, FRANCE, Phone: +33(0)2 23.23.41.90, Email address: j.pawluski@gmail.com / Jodi-lynn.pawluski@univrennes1.fr 


\section{$\underline{\text { Abstract }}$}

Recent research has linked early life exposure to selective serotonin reuptake inhibitor medications (SSRIs) to modifications of social behaviors in children. Serotonin is a key regulator of neurodevelopment, social behaviors and mental health, and with the growing use of SSRIs to treat maternal affective disorders during the perinatal period, questions have been raised about the benefits and risks of SSRI exposure on the developing child. This review will highlight how perinatal SSRIs affect maternal care and neurodevelopmental outcomes related to social affiliative behaviors in offspring; such as play behaviors, social interactions, reproductive behaviors, and maternal care of the next generation. We will also review how early life exposure to SSRIs can alter related neurobiology, and the epigenome. Both clinical research and findings from animal models will be discussed. Understanding the impact of perinatal SSRIs on neurobehavioral outcomes will improve the health and well-being of subsequent generations.

Keywords: Maternal Care, Development, Offspring, Perinatal Depression, SSRI, Pregnancy, Stress, Play behavior, Social interaction, Reproductive behavior, Antidepressant, Sex differences, serotonin, maternal stress, maternal anxiety 


\section{Introduction}

Women are more vulnerable to developing depression than men, with additional susceptibility during childbearing years (Burke et al., 2005; Yonkers et al., 2009). An estimated $10-20 \%$ of women suffer from depression and/or anxiety during the perinatal period (Pawluski et al., 2017). Serotonin reuptake inhibitor antidepressants, such as fluoxetine, sertraline, citalopram and venlafaxine, are prescribed in pregnancy with the expectation that they promote maternal mental health and by extension confer a developmental health benefit to the fetus and child. While this has yet to be confirmed during childhood there is some evidence that SSRIs can alleviate maternal symptoms of peripartum depression and anxiety, and these medications remain the recommended first-line treatment for perinatal affective disorders (Kim et al., 2014). Selective serotonin reuptake inhibitor medications (SSRIs) are the most common treatment for maternal depression and anxiety disorders during the perinatal period (Charlton et al., 2015; Cooper et al., 2007; Oberlander et al., 2006) (Table 1). SSRI use by pregnant women in industrialized countries (including Canada, USA, Australia, Iceland, Denmark, Sweden, UK, Italy, the Netherlands, and France) ranges between 2-7\% in Canada and Western European countries, and between 5-13\% in Australia and the USA (Charlton et al., 2015; Cooper et al., 2007; Hayes et al., 2012; Lupattelli et al., 2014; Oberlander et al., 2006; Zoega et al., 2015) (Table 1).

SSRIs can cross the placenta and can be found in breast milk, raising questions about the safety of using these medications to treat maternal mental illnesses. Indeed, recent clinical findings link prenatal SSRI exposure to abnormal development of social behaviors with increased risk for Autism Spectrum Disorder (ASD) in children prenatally exposed to SSRIs (Kobayashi et al., 2016; Man et al., 2015), and increased externalizing behaviors in young children (Oberlander et al., 2007). In addition to clinical data on social behaviors, animal models are pointing to a 
long-term effect of perinatal SSRIs on social interactions, play behavior, and reproductive behavior; key social affiliative behaviors (Misri et al., 2006; Oberlander et al., 2010; Oberlander et al., 2007; Olivier et al., 2013; Pawluski et al., 2012b). These SSRI effects cannot be completely separated from the effect of maternal mood and maternal care-giving behaviors. Importantly, human studies are frequently challenged by a failure to isolate the effects of the drug exposure from the effects of maternal mental health ("confounding by indication") (Kyriacou and Lewis, 2016) and teasing maternal mood from the interactive effects of SSRIs, maternal/child genetic, health, and environmental factors remains a key challenge in human research. While it is beyond the scope of this review to cover the impact of these factors, a review of this work is needed.

With this in mind, this review will focus on how perinatal SSRIs affect maternal caregiving behaviors in the mother and neurodevelopmental outcomes related to social affiliative behaviors in offspring. These behaviors in offspring include play behaviors, social interactions, reproductive behaviors, and maternal care of the next generation. Both clinical research and findings from laboratory animal models will be reviewed. Specifically we will review the effects of perinatal SSRIs on 1) maternal care-giving behaviors in the mother, 2) offspring social affiliative behaviors, 3) related changes in neurodevelopment, and 4) epigenetic alterations associated with the developing brain and behavior. Understanding the implications of early-life exposure to SSRIs on the development of social behaviors, related neurobiology and epigenome will aid in understanding the risks and benefits of exposure to these medications during the perinatal period. 


\section{SSRIs, maternal care-giving behaviors, and the maternal brain}

Maternal mental illness, such as depression or anxiety, can have detrimental effects on both the mother and the developing child (Almond, 2009; Leung and Kaplan, 2009; Marcus, 2009; Pawluski et al., 2017). These maternal affective disorders are associated with increased risk of preeclampsia, premature delivery, reduced fetal growth, and poor cognitive, emotional, and social development in children (Beversdorf et al., 2005; Huizink et al., 2003; Laplante et al., 2004; Leung and Kaplan, 2009; Olivier et al., 2013; Van den Bergh et al., 2005; Van den Bergh et al., 2008). Mothers with depression, anxiety, and elevated levels of stress often show changes in offspring care-giving behaviors (Brummelte et al., 2006; Hillerer et al., 2012; Maccari et al., 2014; Talge et al., 2007); Depressed and anxious mothers can respond less sensitively, and more negatively, to their infants compared with non-depressed mothers (Field, 1995; Field et al., 1990;

Fleming et al., 1988). Depressed mother-infant dyads also exhibit reduced synchrony with decreases in mutual attention, vocal and visual communications, touching, and smiling compared to healthy controls (Field, 1995; Field et al., 1990). In rodent models, stressed dams spend more time nursing, less time licking offspring and have reduced pup contact (Belnoue et al., 2016; Champagne and Meaney, 2006; Hillerer et al., 2012). As such, changes in maternal care, particularly reductions in licking of offspring, can have long-term effects on offspring outcomes (Meaney, 2001; O'Donnell et al., 2014; Rifkin-Graboi et al., 2015; Wazana et al., 2015).

Although scarce, clinical work shows that SSRIs can affect maternal care-giving. Misri et al (2002) showed that during feeding and free-play, positive infant affect was correlated with maternal sensitivity in SSRI-treated mothers versus untreated mothers. Additionally, positive maternal affect in SSRI treated mothers was negatively correlated with apathetic mood in infants (Misri and Kostaras, 2002; Misri et al., 2004). More recent work, controlling for the effects of 
maternal depression, showed that mothers treated with an SSRI during pregnancy interrupted their child more during play (Weikum et al., 2013). In rodent models, gestational SSRI treatment can increase the frequency of maternal licking of offspring, and in low doses, increase the duration of crouching over offspring (Johns et al., 2005). This is also evident with postpartum SSRI treatment which shows increases in arch-back nursing behaviors, a reduction of maternal self-grooming, and a reversal of the effects of high corticosterone levels on maternal care-giving behaviors (Kiryanova et al., 2016; Pawluski et al., 2012b; Workman et al., 2016). Thus, clinical research and work in animal models show that perinatal SSRIs can alter maternal care-giving behaviors, and these effects may protect against the effects of maternal stress-related disorders.

\subsection{Serotonin and Maternal care-giving}

There is a wealth of literature that examines the roles of hormones like oxytocin, prolactin, progesterone, and estradiol on the initiation and maintenance of maternal behavior (Bridges, 2015). However, less is known about the function of serotonin-related mechanisms involved in maternal behavior. Together, hormonal signals and serotonin may work in concert to regulate maternal behavior. Indeed, hormone receptors exist on serotonergic neurons in the midbrain raphe nuclei (Chalmers et al., 1995; Yoshida et al., 2009; Yoshimura et al., 1993) and projections from these neurons, as well as serotonin receptors, aid in regulating hormonal activity in the hypothalamus (Bagdy, 1996; Ito et al., 2014; Jorgensen et al., 2003) and other related brain regions (Steinbusch, 1981) implicated in the maternal caregiving network (Barrett and Fleming, 2011). Therefore, serotonergic changes which occur in the female brain during pregnancy and the postpartum period may impact maternal behavior (Lonstein et al., 2014; Numan et al., 2006). For instance, compared to virgins, serotonin turnover is lower in rat dams in the ventral bed nucleus of the stria terminalis (Smith et al., 2013) and in the medial preoptic area (Lonstein et al., 2003). 
This suggests that serotonin metabolism is altered in brain regions critical for mediating parental behaviors. Some of these neurochemical changes are only apparent during the early postpartum period; early postpartum dams have higher 5-hydroxytryptophan (5-HTP) and 5hydroxyindoleacetic acid (5-HIAA), both critical metabolites involved in serotonin synthesis, in the dorsal raphe compared to virgin and late postpartum rats (Holschbach and Lonstein, 2016). Therefore, particular perinatal time points may serve as critical periods of serotonin sensitivity.

Pup contact can also affect central serotonin mechanisms during the postpartum period. Upon contact with pups after brief separation, maternal serotonin release increases in the ventral striatum (Hansen et al., 1993; Lerch-Haner et al., 2008) and decreases 5HT 1 A receptor levels throughout the limbic system (Stamatakis et al., 2015). Relatedly, in adult virgin female rats exposed to pups as juveniles, protein expression of tryptophan hydroxylase 2 (TPH2), a brain and central nervous system specific enzyme required for serotonin synthesis, is similar to expression in early postpartum dams in the dorsal raphe (Harding and Lonstein, 2016). Thus pup exposure can modify the serotonergic system in the maternal brain.

Several animal models have shown that serotonin plays a role in mediating specific aspects of maternal behavior such as maternal responsivity. For example, in the medial prefrontal cortex (mPFC), TPH2 is negatively associated with maternal licks of pups (Ragan et al., 2016). In non-human primates, rhesus macaque mothers with low cerebrospinal fluid (CSF) levels of 5HIAA are more protective of their infants than mothers with high CSF 5-HIAA (Fairbanks et al., 1998; Lindell et al., 1997). In humans, mothers with the short (S) or similar L(G) allele for the serotonin-transporter (SERT) promoter show more sensitive mothering styles compared to mothers without these alleles (Mileva-Seitz et al., 2011). Maternal responsiveness can also be observed in nulliparous females after continuously exposing them to young pups in a maternal 
sensitization paradigm (Lonstein et al., 1999; Rosenblatt, 1969). Unlike dams, TPH2 in the $\mathrm{mPFC}$ is positively associated with maternal responsivity in sensitized virgins (Ragan et al., 2016). Therefore, maternal experience and pup exposure likely have a significant impact on aspects of serotonergic functioning and these effects can differ in parturient and virgin females.

Targeted lesioning of serotonergic neurons in the median raphe nucleus severely impairs pup retrieval and nursing (Barofsky et al., 1983). In addition, Pet-1 (a transcription factor specific to normal functioning of serotonergic neurons) knockout mouse dams show severely disrupted nest-building and retrieval, resulting in low pup survival (Lerch-Haner et al., 2008). Similarly, TPH2 knockout mouse dams display reduced arched-back nursing postures and pup retrieval, disrupted nest building, increased pup cannibalism, and less aggression to an intruder compared to wild types (Alenina et al., 2009; Angoa-Perez et al., 2014). In rats, postpartum treatment with a 5- $\mathrm{HT}_{2 \mathrm{~A} / 2 \mathrm{C}}$ receptor antagonist, clozapine, decreases nursing and pup retrieval possibly via altered signaling in the nucleus accumbens (Zhao and $\mathrm{Li}, 2010$ ). These effects of a 5-HT2A/2C receptor antagonist can be rescued by a $5 \mathrm{HT}_{2 \mathrm{~A} / 2 \mathrm{C}}$ receptor agonist (2,5-dimethoxy-4-iodo-amphetamine) which reduces the amount of time it takes rats to initiate contact and retrieve pups, as well as increases the time spent licking pups (Zhao and Li, 2010). Others have shown that more targeted injections of a $5 \mathrm{HT}_{2 \mathrm{~A}}$ antagonist (cis-flupenthixol), in the nucleus accumbens on postpartum day 6 increases crouching behavior duration (Keer and Stern, 1999). Such work demonstrates that normal serotonin functioning, particularly in relation to the $5 \mathrm{HT}_{2 \mathrm{~A}}$ receptor, is critical for positive maternal care.

Recent work also shows significant changes in neuroplasticity in response to motherhood in the midbrain dorsal raphe nucleus, the source of most ascending serotoninergic projections (Holschbach and Lonstein, 2017), and in other regions of the maternal brain; SSRIs increase 
neurogenesis in the maternal hippocampus (Pawluski et al., 2017; Pawluski et al., 2012b) and alter plasticity in the PFC and amygdala (Haim et al., 2015; Haim et al., 2014). Postpartum fluoxetine treatment also decreases both global measures of methylation in the dentate gyrus and serotonin metabolism in the hippocampus, but not the prefrontal cortex (PFC), of the mother (Gemmel et al., 2016). Together, these results show that central activation of serotonin-related mechanisms can promote maternal behaviors and alter plasticity in the maternal brain. Thus, emerging evidence points to the valuable role of serotonin, and its mediation by SSRIs, on the brain and behavior of the mother. As such, these changes in maternal care-giving behaviors, altered by perinatal SSRIs, can shape the neurobehavioral development of offspring.

\section{Perinatal SSRIs and social behaviors}

Serotonin is heavily involved in the development of social responses, and early modulation of this system via developmental exposure to SSRIs can significantly alter social interactions later in life (Crockett et al., 2010; Kiser et al., 2012; Tonissaar et al., 2004). Prenatal SSRI exposure is linked to increased risk for mood disorders, Autism Spectrum Disorder (ASD), and altered reproductive behavior in offspring (Misri et al., 2006; Oberlander et al., 2010; Oberlander et al., 2007; Olivier et al., 2013; Pawluski et al., 2012b). Note there is a substantial amount of literature documenting effects of perinatal SSRIs on affective disorders which is beyond the scope of this review (for review see (Glover and Clinton, 2016; Homberg et al., 2010;

Oberlander et al., 2009; Pawluski et al., 2012c; Pinna, 2015)).

\subsection{Clinical outcomes: SSRIs and offspring social behaviors}

Recent research has raised intriguing questions about the link between perinatal SSRI exposure and the development of ASD (Man et al., 2015). While previous studies found no association between ASD and prenatal SSRIs after controlling for maternal depression (Clements 
et al., 2015), recent meta-analysis studies support the increased risk of ASD in children prenatally exposed to SSRIs (Kobayashi et al., 2016; Man et al., 2015), although maternal depression indeed serves as a confounding factor. Exposure to maternal depression and SSRIs may both contribute to neurodevelopmental disorders such as ASD, as both lead to imbalanced fetal serotonin, a key regulator in overall development and the development of specific behavior-mediating brain tissues (Muller et al., 2016; Whitaker-Azmitia, 2001). Such work supports the idea that early life SSRIs can contribute to numerous behavioral pathologies which likely alter the trajectory of social behaviors.

In line with this, an increasing amount of clinical data documents the effect of perinatal SSRIs on behavioral development in children. Infants exposed to SSRIs during gestation exhibit blunted emotional and physical response to painful stimuli at two months of age, and low adaptive and social-emotional behavioral scores at 10 months of age (Hanley et al., 2013; Oberlander et al., 2002; Oberlander et al., 2005). Prenatal exposure to SSRIs increases Pervasive Developmental Disorder scale scores at 2-5 years of age (Johnson et al., 2016) and externalizing behavior beyond the clinical cutoff in children 4 years of age (Hermansen et al., 2016; Oberlander et al., 2007). Such work indicates that perinatal SSRIs can increase aggression, attention/hyperactivity, and oppositional or defiant behaviors, and negatively impact social interactions in early childhood. In addition, children 3 and 4 years of age exposed prenatally to SSRIs and maternal depression also exhibit increased internalizing behaviors (depression, anxiety, and withdrawal) (Oberlander et al., 2010). Similarly, prenatal SSRIs, after controlling for maternal depression, can increase the risk for attention deficit hyperactivity disorder in children 2 to 19 years of age (Clements et al., 2015). In summary, clinical research to date demonstrates a 
complex relationship between early life exposure to SSRIs and maternal mood disorders, on mediating behavioral outcomes and social interactions throughout life.

As serotonin is known to play a crucial role in social interactions (Homberg et al., 2007; Kiser et al., 2012; Muller et al., 2016; Whitaker-Azmitia, 2001), a growing body of animal research seeks to understand how perinatal SSRIs can impact social affiliative behaviors in offspring. The following section reviews how perinatal SSRIs affect play behavior, social preference, reproductive behavior, and maternal care of subsequent generations in animal models. Although much of this research is done in healthy dams and offspring, the effects of perinatal SSRIs can differ when using a model of aspects of maternal depression; which is arguably the more appropriate model. When they exist, these effects will be pointed out below and in Table 2 . For further discussion of the importance of using a model of maternal stress see section 5.

\subsection{Animal models: Perinatal SSRIs and Juvenile Play Behavior}

Social play behaviors are important for establishing interaction strategies and social responses later in life which aid in establishing coalitions, social dominance, mating, and maternal responses (Kiser et al., 2012). Rodent social play behavior is well-categorized and includes specific behaviors with a novel conspecific such as pinning, pouncing, following/chasing, and boxing/wrestling (rather than social interaction preference as measured in the object/conspecific task discussed below). Increasing research shows that perinatal SSRIs can mediate such social play behavior responses in offspring. Prenatal fluoxetine exposure tended to reduce male and female social play in juveniles by reducing the frequency of pinning, boxing/wrestling, and social exploration of a novel social partner (Olivier et al., 2011a)(Table 2). This effect persisted into adulthood with adult rodents having reduced frequencies of social exploration with a novel social partner (Olivier et al., 2011a). Similar reductions in social play 
are evident when SSRI treatment occurs during the early postnatal period. Citalopram or fluoxetine administration reduces the frequency of boxing/wrestling behavior, following/chasing, and rearing in juvenile male and female rats (Khatri et al., 2014; Rodriguez-Porcel et al., 2011). Interestingly, postnatal SSRIs likewise increase the frequency of stereotypic behavior in these animals (Khatri et al., 2014; Rodriguez-Porcel et al., 2011), an additional clinical indicator of ASD. SSRI-dependent modifications to social response can also be mediated by offspring sex:. Postnatal citalopram administration reduces the frequency of pinning, stereotypic behavior, and social play behaviors, in juvenile male, but not female, offspring (Rodriguez-Porcel et al., 2011). When taken together, animal work suggests reduced play behavior following perinatal SSRIs which may be indicative of neurodevelopment disorders and deficits in social response and social behaviors.

Similar to clinical findings which point to the role of SSRI exposure in increasing the risk of ASD, animal models highlight the role of serotonin as a key neurobehavioral regulator of social play. Serotonin transporter knock-out rats, or those exposed to fluoxetine or MDMA (which similarly slows serotonin and monoamine re-uptake) display reductions in the number of pins, pounces, and boxing bouts, as well as increased time spent following social partners in the juvenile period (Homberg et al., 2007). Early life changes to the serotonergic environment, therefore, contribute to reduced-social play behavior and modifications to behavioral phenotypes (Kiser et al., 2012).

\subsection{Animal models: Perinatal SSRIs and Social Interaction Preference}

Social interactions with novel conspecifics are often studied in laboratory animals in order to assess additional aspects of social behavior, such as social preference. Typical behavioral assays include exploration of a novel conspecific versus exploration of a novel object, approach- 
avoidance tests with a novel caged conspecific, or non-constrained social interaction test. Expanding clinical findings, research in rodent models shows that early life SSRI exposure affects social interactions with novel same-sex conspecifics. Offspring treated with SSRIs postnatally show decreased conspecific exploration compared to novel object exploration in juvenile and adult male and female rat offspring (Khatri et al., 2014; Rodriguez-Porcel et al., 2011; Simpson et al., 2011; Zimmerberg and Germeyan, 2015). However, prenatal SSRIs increase social preference in the novel object/conspecific test in juvenile female offspring (Svirsky et al., 2016), suggesting that behavioral outcomes after postnatal SSRI exposure may differ from prenatal SSRI exposure outcomes and with offspring sex. Even more transient, fluoxetine administration from PD 0-4 increases the frequency of sniffing and contact behavior in adult male rat offspring as well as total social interaction time with novel social controls (Ko et al., 2014). Thus, the timing of perinatal SSRI exposure can differentially alter social behaviors.

Perinatal SSRIs also mediate aggression and aggressive-like social interactions in offspring. Perinatal fluoxetine exposure increases the number of adult male aggressive behavior counts, as well as duration of aggressive behavior in mice (Kiryanova and Dyck, 2014; Svirsky et al., 2016). This effect is again both age and sex dependent, as juvenile mice, and female offspring at any age, do not show any differences in aggressive interaction compared to controls (Svirsky et al., 2016). This is in line with a growing body of literature showing that serotonergic system dysfunction, such as TPH inactivation, can increase social aggression in rodents (Kiser et al., 2012; Lesch et al., 2012). Therefore, early life modification of serotonergic functioning via SSRI exposure can alter social preferences and aggression and these effects may be further mediated by offspring sex. 


\subsection{Animal Models: Perinatal SSRI and Reproductive Behaviors}

There is a long-term impact of perinatal SSRIs on social reproductive behaviors in male and female offspring (Harris et al., 2012; Maciag et al., 2006b; Rayen et al., 2013a, 2014). This is perhaps not surprising given the role of serotonin in sexual differentiation of the brain and behavior (Dohler et al., 1991).

Male offspring. Mirmiran et al (1981) were the first to report that early postnatal exposure to the tricyclic antidepressant, chlorimipramine, leads to a reduction in sexual behavior in adult male rat offspring (Mirmiran et al., 1981). Others expanded these findings by showing that neonatal exposure to the tricyclic antidepressant, clomipramine leads to diminished sexual behavior in male rat offspring; including decreases in mounting, intromission and ejaculatory behavior (Vogel et al., 1990). More recently, research on how perinatal SSRIs impact male sexual behavior shows that only postnatal exposure to SSRIs affects sexual behavior. Postnatal exposure to SSRIs disrupts male sexual behavior resulting in decreased sexual motivation, fewer mounts, intromissions, and ejaculations (Gouvea et al., 2008; Harris et al., 2012; Maciag et al., 2006b; Rayen et al., 2013b; Rodriguez-Porcel et al., 2011), while prenatal SSRIs have no effect on male copulatory behavior (Cagiano et al., 2008; Olivier et al., 2011b). This impairment in sexual behavior in male rats postnatally exposed to SSRIs is mimicked by the stimulation of the 5-HT1B receptor and partly by stimulation of the 5-HT1A and the 5HT2 receptors (Harris et al., 2012; Maciag et al., 2006a; Maciag et al., 2006b; Wilson et al., 1998), indicating a contribution of the serotonin autoreceptors during development on male sexual behavior.

Though serotonin signaling plays an important role in the development of male sexual behaviors in rodents, it appears to be altered in the context of maternal stress (more analogous to the clinical situation). If postnatal fluoxetine exposure occurs after prenatal maternal stress, there 
is no effect of postnatal fluoxetine on male sexual behavior (Rayen et al., 2013b). This suggests that the effects of perinatal SSRIs on male sexual behavior appears only when given to healthy dams and/or offspring, and that maternal stress can alter sexual differentiation in such a way that limits the effects of perinatal SSRIs on copulatory behaviors in male offspring.

Female offspring. In contrast to the effects in male offspring, early life exposure to fluoxetine facilitates proceptive and receptive behaviors in adult female offspring, regardless of exposure to maternal stress (Rayen et al., 2014). Although this is the only work showing the effects of perinatal SSRIs on female copulatory behaviors, the actions of serotonin on sexual differentiation in the developing female are dependent on the timing of serotonergic manipulations, and often show a down regulation of female sexual behavior if the manipulation occurs during the first week of life. For example, stimulation of serotonin synthesis on postnatal days 1-7 results in an inhibition of lordosis behavior (Dohler et al., 1991; Jarzab and Dohler, 1984) and treatment with a serotonin synthesis inhibitor between postnatal days 1 and 7 reduces proceptive behaviors (Dakin et al., 2008). Together, these findings suggest that the timing of the SSRI exposure during the perinatal period can differentially affect the development of female reproductive behaviors with prolonged exposure to SSRIs feminizing the female brain and behavior.

\subsection{Animal Models: Perinatal SSRIs and offspring maternal care}

Given the growing literature on the effects of serotonin on maternal care, it is perhaps not surprising that perinatal SSRIs alter maternal behavior in female offspring. However, to date only one study has been done in this area and findings from this work show that prenatal fluoxetine can reduce maternal behaviors of female offspring when they are mothers by reducing nest quality and delaying pup retrieval (Svirsky et al., 2016). Interestingly, these same prenatally 
SSRI-exposed female offspring showed more adaptability in maternal behaviors, with greater improvements in maternal care on postnatal day 2 and 3 than controls (Svirsky et al., 2016). Similarities can be drawn between dams receiving direct SSRI treatment, and female offspring exposed to SSRIs while in utero, with such medications increasing aspects of maternal care. This work suggests that periantal SSRIs may make female offspring more resilient mothers, although this is likely still dependent on the duration and timing of SSRI exposure.

\section{Perinatal SSRI effects on Related Changes in Neurobiology}

Numerous brain regions contribute to the regulation of social affiliative behaviors. With regards to perinatal SSRI effects, the hypothalamus, hippocampus, and PFC have received the most attention, as these regions play a role in mediating social, emotional, and cognitive processes throughout the lifespan (Andrews and Matthews, 2004; Courchesne and Pierce, 2005; Eisch et al., 2008; Laplante et al., 2002; McEwen, 2005; Meaney et al., 1994). Serotonin, which is highly involved in regulating social behavior, social response, and serotonergic system functioning, receives afferent information about behavioral outcomes, and can have a substantial impact on these brain regions and their development (Glover and Clinton, 2016; Kiser et al., 2012). Understanding how fluctuations in serotonin and serotonergic system functioning impact developing neurobiology via early life SSRI exposure is critical in integrating what we know about the development of social affiliative behaviors in offspring.

Below, we will cover what is known about the effects of SSRIs on the serotonergic system as well as the hypothalamus (a mediator of copulatory behaviors and stress), the hippocampus (a primary player in cognition), the prefrontal cortex (a regulator of executive 
functions), and the amygdala (a primary player in emotional reactions). For a review of how SSRIs affect the dorsal raphe specifically, see (Glover and Clinton, 2016).

\subsection{Serotonin, SSRIs, and brain development}

In the developing brain, consequences of early life exposure to SSRIs may not occur immediately after birth, but may manifest later during childhood, adolescence or even in adulthood. The literature already demonstrates an effect of perinatal SSRIs on offspring serotonergic development, which has potential implications for neurodevelopmental delay and behavioral dysfunction. Early-life SSRIs result in an increase in acute serotonergic tone in clinical studies (Homberg et al., 2010; Oberlander et al., 2009) and suppress central serotonergic tone in adult preclinical studies, likely related to increased auto-inhibitory feedback (Maciag et al., 2006b; Simpson et al., 2011; Weaver et al., 2010). Research in animal models also show that early-life exposure to SSRIs reduces adult TPH and SERT expression in the dorsal and medial raphe (Maciag et al., 2006b; Maciag et al., 2006c), as well as in the hippocampus and cortex at both the juvenile and adult ages (Maciag et al., 2006c; Simpson et al., 2011; Weaver et al., 2010). Therefore, alterations in serotonergic functioning evident at the clinical and preclinical level suggest an effect on developing brain regions critical for mediating neurobehavioral outcomes in offspring after perinatal SSRI exposure.

\subsection{Clinical findings}

Findings from clinical studies are beginning to point to an effect of prenatal SSRIs on

fetal and neonatal neurodevelopment by investigating biomarkers in peripheral fluids which are related to central nervous system development. After controlling for levels of maternal depression, prenatal SSRIs decreases S100B, an astroglial-specific calcium-binding protein (Haring et al., 1993; Whitaker-Azmitia et al., 1990), in human neonates at birth (Pawluski et al., 
2009b). S100B mediates the positive outgrowth and survival of neurons (Bhattacharyya et al., 1992; Gonzalez-Martinez et al., 2003), and stimulates glial cell proliferation (Selinfreund et al., 1991). Therefore, decreased S100B levels in human biological fluids may be a useful indicator of reduced brain maturation and neural development following perinatal SSRI exposure (Pawluski et al., 2009b). In addition, reelin levels are decreased in neonates prenatally exposed to SSRIs (Brummelte et al., 2013). Reelin is a glycoprotein which plays a critical role in neuronal migration and positioning during neurodevelopment, again suggesting effects of SSRI exposure on the brain of developing offspring. Recent imaging data has confirmed that prenatal SSRIs do indeed alter the developing brain, with prenatal SSRIs decreasing activity in the basal ganglia and thalamus of preterm neonates (Podrebarac et al., 2016). Reduced activity in key brain regions during infancy as a result of prenatal SSRIs may provide insight into how altered neural development plays a role in mediating behavior. To gain insight into the specific neurobiological effects of perinatal SSRIs on development, animal models have been used. Below is a brief summary of findings following perinatal SSRIs on the most critical regions involved in social behavior regulation.

\subsection{Animal Models: Hypothalamus}

The hypothalamus plays a central role in two key physiological systems that act to mediate a number of behavioral responses: the hypothalamic-pituitary-adrenal (HPA) and gonadal (HPG) axes. With regards to the HPA system, a key regulator of stress, mood, emotional responses and social behaviors (Albers, 2012; Kaldewaij et al., 2016), research findings to date show that prenatal SSRIs reduce cortisol levels in human infants (Brennan et al., 2008; Davidson et al., 2006; Davidson et al., 2009; Oberlander et al., 2008a) and these effects are related to increased corticosteroid binding globulin (CBG) levels in SSRI-exposed neonates (Pawluski et 
al., 2012a). Animal work shows a similar effect of perinatal SSRIs on the developing HPA system with prenatal SSRIs increasing cortisol levels in fetal lamb plasma (Morrison et al., 2004), and adrenocorticotrophic hormone and cortisol levels in infant rhesus monkeys after maternal separation (Clarke et al., 1998). Postnatal SSRIs significantly decreases corticosterone levels in adolescent male, but not female, rat offspring (Pawluski et al., 2012c). Similar to human neonates, postnatal SSRI exposure also increases CBG levels, but only in prenatally stressed male offspring (Knaepen et al., 2013; Pawluski et al., 2012c). Thus, with perinatal SSRI effects on the developing HPA system, it is likely that these changes alter many aspects of social behaviors.

With regards to the HPG axis, and in relation to findings on the effect of perinatal SSRIs on reproductive behaviors discussed above, it is not surprising that early life exposure to SSRIs are associated with changes in the medial preoptic area (MPOA) (Rayen et al., 2013a; Soga et al., 2012). Previous work shows that postnatal SSRIs, as well as maternal stress, significantly decrease the area of the sexually dimorphic nucleus of the medial preoptic area (SDN-POA), a sexually differentiated brain area, in adult male offspring (Rayen et al., 2013b). Interestingly, postnatal fluoxetine exposure has little effect on the female SDN-POA area, anteroventral periventricular nucleus (AVPv), or and volume of the posterior bed nucleus of the stria terminalis (pBST) in adult male or female offspring (Rayen et al., 2013b, 2014). Others have shown that early life exposure to SSRIs leads to a significant reduction in the number of androgen receptorimmunoreactive cells in the MPOA (Soga et al., 2012). Although activation of estrogen receptors by estrogenic metabolites of testosterone is critical to induce masculinization, male sexual behavior, and de-feminization of the brain, androgen receptors are required for perinatal testosterone to induce complete masculinization of the brain and behavior (Sato et al., 2004). Furthermore, inhibition of the natural postnatal drop in serotonin, resulting from maternal SSRI 
treatment, likely antagonizes the perinatal masculinization effects of testosterone during the second and/or third week postpartum (Jarzab and Dohler, 1984; Wilson et al., 1998; Wilson et al., 1986).

\subsection{Animal Models: Hippocampus}

Recent work highlights the role that monoamine functioning and plasticity in the hippocampus plays in modulating peer-to-peer social behaviors (Hammels et al., 2015; Hitti and Siegelbaum, 2014; Stevenson and Caldwell, 2014). The hippocampus is one of two brain regions where there is a remarkably high rate of neurogenesis throughout the lifespan (the other region being the subventricular zone) (Eriksson et al., 1998; Pawluski et al., 2009a). New neurons, changes to structural plasticity, and monoamine functioning in the hippocampus are thought to play an important role in learning and memory, stress regulation, and social behaviors (Dranovsky and Hen, 2006; Hammels et al., 2015; Santarelli et al., 2003; Toffoli et al., 2014; Vialou et al., 2013). For example, the CA2 region, which links the CA1 and CA3 regions (Sekino et al., 1997), plays a prominent role in the regulation of social behavior. Selective lesions to the rodent $\mathrm{CA} 2$ region impair social recognition memory via reductions in the ability of an animal to remember a conspecific (Hitti and Siegelbaum, 2014; Stevenson and Caldwell, 2014). Therefore, understanding how monoamine functioning and neuroplasticity may be affected by perinatal SSRIs will clarify the role of these medications on social development.

Perinatal SSRIs affect monoaminergic functioning and neurogenesis in the hippocampus of offspring, and can act to normalize the effects of maternal stress on the developing brain (Ishiwata et al., 2005; Lee et al., 2001; Nagano et al., 2012; Rayen et al., 2015; Rayen et al., 2011). For example, postnatal SSRIs normalize levels of serotonin, and 5-HIAA, in prenatally stressed offspring at weaning (Gemmel et al., 2015) and reverse the effects of maternal stress on 
hippocampal neurogenesis in adolescent offspring and, to some extent, in adult offspring (Rayen et al., 2015; Rayen et al., 2011). Early-life SSRI treatment also reverses the reduction in CA3 spine and synapse density observed in prenatally stressed juvenile and adolescent male mice (Ishiwata et al., 2005). In addition, postnatal SSRI treatment leads to upregulation of hippocampal brain derived neurotrophic factor (BDNF) mRNA in adult rat offspring (Karpova et al., 2009), which suggests an additional mechanism by which perinatal SSRIs can restore neuronal development. When exposed postnatally to fluoxetine alone, hippocampal neurogenesis is significantly decreased in adolescent offspring (Rayen et al., 2011), highlighting the importance of work which investigates to the effects of perinatal SSRI exposure using a model of maternal stress.

Work in adult rodent offspring shows a persistent effect of sex in mediating hippocampal neurodevelopment following perinatal SSRIs. Adult female offspring, but not male offspring, exposed to postnatal fluoxetine have increased new cell survival and reductions in hippocampal synaptophysin density in the granule cell layer (Rayen et al., 2015). Others have shown that postnatal SSRIs increase immature neuron density in the hippocampus of adult male offspring, while reducing such density in the adult female hippocampus (Gobinath et al., 2016). Apart from the effects of serotonin on sexual differentiation of the brain and behavior (Dohler et al., 1991; Jarzab and Dohler, 1984), changes in steroid hormone levels during puberty may contribute to sex-dependent SSRI sensitivity and plasticity changes in the hippocampus (Galea, 2008; Galea et al., 2006; Tabori et al., 2005; Weiland et al., 1997), thereby differentially affecting cell proliferation and new cell survival. Thus, sex-dependent changes in hippocampal neurogenesis may be related to sex-dependent changes observed in social and reproductive behavior; this would be in line with previous work showing a link between hippocampal neurogenesis, 
reproductive behaviors, and social interactions (Gould and Zingg, 2003; Hammels et al., 2015; Leuner et al., 2014; Leuner et al., 2010).

\subsection{Animal Models: Prefrontal Cortex}

The PFC, vital for cognition, decision making, complex thought, and integration, plays an extensive role in emotion, anxiety, and behavior (Jin and Maren, 2015; Shiba et al., 2016). Disrupted interactions between the hippocampus and PFC contribute to multiple psychiatric disorders, including phobias, schizophrenia, and depression (Godsil et al., 2013; Maren et al., 2013; Sigurdsson et al., 2010). As a result, it is not surprising that treatment of maternal psychiatric disorders during the perinatal period may affect the development and functioning of the PFC in offspring, and thus, may play a role in mediating social behavior.

Perinatal SSRIs can both decrease and increase functioning of the serotonergic system in the PFC and these effects can vary with maternal stress. For example, early-life SSRIs can decrease serotonin levels and SERT expression in offspring (particularly in males) (Cabrera-Vera et al., 1997; Maciag et al., 2006b; Xu et al., 2004; Zhou et al., 2015) and increase 5-HT2A receptor expression in offspring (Sarkar et al., 2014b). Interestingly, reduced SERT-ir density in the mPFC after postnatal SSRIs can, be restored with behavioral training by the repetition-rate discrimination task (Zhou et al., 2015). Reductions in SERT-ir density in the cortical barrel of male and female rat offspring postnatally exposed to paroxetine were also associated with reduced cortical area (Xu et al., 2004), suggesting an impact on additional brain regions which rely on the cortex for afferent and efferent information.

When using a model of maternal stress, early-life exposure to SSRIs reverses reductions in 5HT1A receptor expression in GABAergic cells in the mPFC of gestationally stressed male, but not female, rats (Zohar et al., 2014) and normalizes BDNF levels in the mPFC after prenatal 
stress (Nagano et al., 2012). Early life SSRIs can also affect the dopaminergic system, protecting against the effects of maternal stress by restoring homovanillic acid levels (one of dopamine's metabolite) in the PFC of prenatally stressed rat offspring at weaning (Gemmel et al., 2015).

Due to altered monoamine function following early life SSRI exposure, it is not surprising that perinatal SSRIs affect neurodevelopment in the PFC. Perinatal SSRIs alter callosal connections by distorting myelin sheath formation in male and female rats (Simpson et al., 2011). Postnatal SSRIs impact numerous neuronal cell types, reducing dendritic spine density in medial spiny neurons (Lee and Lee, 2012), spiny stellate cells and thalamocortical afferents (Lee, 2009), as well as reducing dendritic length of subplate neurons, which are critical for cortical development (Liao and Lee, 2011). Prenatal SSRIs also reduce dendritic branching in pyramidal neurons of cortical layers in adult mice (Smit-Rigter et al., 2012), while early postnatal SSRIs increase dendritic branching of pyramidal neurons in the mPFC and reduce dendritic spines in adult male rats (Ko et al., 2014). Such work suggests a trajectory of cortex development that is dependent on a critical period of SSRI exposure. The exact role of these changes in neurodevelopment on social behaviors remain to be determined, but it is likely that changes in neuron morphology and the serotonergic system are critical in aspects of social affiliative behaviors, such as social cognition.

\subsection{Animal Models: Amygdala}

The amygdala plays a critical role in regulating emotion, memory, and decision making, mediating social interaction and social behaviors (Kaldewaij et al., 2016), and is involved in neurodevelopment disorders such as ASD (Groen et al., 2010). Perinatal SSRIs are associated with a variety of changes within the amygdala of male offspring; however, only limited work has investigated effects in female offspring. Following perinatal SSRIs, male, but not female, rat 
offspring display a decrease in the immediate early-gene product c-Fos following restraint stress in the basolateral and medial amygdalar nuclei (BLA, MeA), indicating lower neuronal activation in these areas (Francis-Oliveira et al, 2013). Gestational exposure to maternal fluoxetine is also associated with increases in SERT density in the BLA and MeA of juvenile male offspring (Cabrera-Vera et al., 1998). While no behavioral assessments were included in this study, other investigators have found that a brief postnatal treatment with fluoxetine is associated with changes dendritic spine architecture in the BLA (Ko et al., 2014). The authors postulate that these changes may be associated with impaired prepulse inhibition performance; fluoxetine exposure was also associated with hypolocomotion and increases in social behavior (Ko et al., 2014). As mentioned previously, SSRIs work primarily by inhibiting the reuptake of serotonin from the cleft, thus increasing its signaling activity. Similar effects are produced by increasing the amount of serotonin in the cleft via other means, or introducing a serotonin receptor agonist such as 5methoxytryptamine (5-MT); perinatal exposure and treatment with 5-MT led to more calcitoningene related peptide projections to the medial and lateral central amygdalar nucleus, as well as a decrease in oxytocin-containing cells in the paraventricular nucleus of the hypothalamus, which may also be associated with changes in social behavior and novelty-related behavior (McNamara et al., 2008). Others have shown that perinatal paroxetine exposure to rats at 'high risk' for depressive-like behavior significantly changes gene expression profiles in the amygdala and hippocampus at several developmental time points, suggesting a long-term pervasive effect of SSRIs on the developing brain (Glover et al., 2015).

Taken together, there are pervasive effects of perinatal SSRIs on the developing brain. These effects may protect against the effects of maternal stress, but also may independently alter neural circuitry vital for a number of behavioral outcomes important for social recognition, 
communication, and cognition. Beyond changes in neuroplasticity, epigenetic mechanisms may also be implicated in the effects of perinatal SSRIs on social affiliative behaviors. Below we will review what is known about the effects of perinatal SSRIs and epigenetic mechanisms.

\section{Perinatal SSRIs and Epigenetic mechanisms}

Epigenetic mechanisms regulate gene expression via covalent modifications to the DNA and associated proteins. Epigenetic changes, such as DNA methylation or chromatin modifications, can be acquired over the lifespan and mediate environmental effects on gene expression. Recent evidence suggests that epigenetic programming represents a key player in explaining the developmental origins of adult health and disease (DOHaD) concept and is thus also likely to contribute to the programming effect induced by perinatal SSRI exposure. While adult antidepressant-induced epigenetic changes generally seem to be beneficial, their impact on developmental epigenetic programming of brain function and behavior may be largely detrimental.

\subsection{Epigenetics and Social Behavior}

In the brain, epigenetic regulation is vital for basic cellular processes and for complex behaviors such as those involved in mediating various cognitive and affective phenotypes. Epigenetics plays a fundamental role in nervous system development by regulating neuronal differentiation, neurogenesis, and plasticity, which, as discussed above, are implicated in behavior, cognition, memory, and neuropsychiatric disorders (Champagne, 2010; Ravi and Kannan, 2013; Svrakic and Cloninger, 2010). Maternal care-giving experience and exposure to perinatal stress can likewise result in epigenetic modifications, such as DNA methylation and histone modifications, which play a role in mediating neuronal growth in neurobiological 
pathways regulating stress, cognition, and behavior throughout life (Gudsnuk and Champagne, 2012; Szyf, 2011). Changes to neuronal growth and development, as regulated by the epigenome, appear to play a role in multiple neuropsychiatric and developmental behavioral disorders including ASD, schizophrenia, epilepsy, and intellectual disabilities (Banerjee et al., 2014). Such work highlights a clear connection between epigenetic programming following exposure to early life stress and adversity, and offspring social behavior (Patchev et al., 2014). A reciprocal interaction appears to exists; early life environment and social experience mediate epigenetic changes which can further mediate social and affiliative behaviors across the lifespan (Champagne, 2012; Crews, 2010; Keverne and Curley, 2008; McGowan and Szyf, 2010; Szyf, 2013). In addition, perinatal experience and subsequent epigenetic modifications may play a critical role in mediating offspring behavior and mental health in ways which are dependent on the timing of early life adversity exposure (Provencal and Binder, 2015), similar to timedependent effects of SSRIs on behavioral and neurological development. Epigenetic mechanisms also mediate sexual differentiation, which, as previously mentioned, plays a role in determining the development of social reproductive behavior (Kigar and Auger, 2013). Therefore, it is likely that social plasticity is mediated not only at the physiological and neural level, but also at the genomic level (Cardoso et al., 2015), and that changes to the offspring epigenome with prenatal SSRIs plays a key role in mediating the development of social behaviors.

\subsection{Clinical outcomes}

A recent systematic review could not establish a clear association between use of (various classes of) antidepressant medication during pregnancy and epigenetic changes in the umbilical cord blood (Viuff et al., 2016). However, one of those studies, a genome-wide methylation study specifically addressing the role of SSRIs, identified increased methylation levels at CpG sites 
(where a cytosine nucleotide is followed by a guanine nucleotide in the linear sequence of bases) in the CYP2E1, EVA1 and SLMAP genes (Gurnot et al., 2015). Moreover, that same study also found a strong correlation between maternal mood scores and CYP2E1 DNA methylation values only in those newborns exposed to SSRIs, but not in unexposed newborns of depressed mothers, suggesting a mood and drug interaction. Another genome-wide study by Non et al. (2014) identified several $\mathrm{CpG}$ sites of which cord blood methylation levels were significantly different when comparing depressed mothers without medication to healthy controls. Among others, the COL7A1 gene coding for a part of collagen VII showed differential methylation in this respect. However, no significant differences in methylation levels were found when comparing those exposed to SSRIs in pregnancy to controls (Non et al., 2014).

Several other studies addressing cord blood methylation made use of a candidate-based approach. For example, Oberlander and colleagues (2008) studied the degree of methylation at the $N R 3 C 1$ locus in both maternal and neonatal blood samples and found that children of women with mid-to-third trimester depressed mood displayed increased levels of DNA methylation at various $\mathrm{CpG}$ sites within exon $1 \mathrm{~F}$ of $\mathrm{NR} 3 \mathrm{Cl}$ in the umbilical cord blood. They also found that maternal depressed mood during the second trimester was associated with increased methylation levels at one of those same $\mathrm{CpG}$ sites in the newborn. However, they found no association between use of SSRIs during pregnancy and the degree of methylation in the cord blood of the newborn (Oberlander et al., 2008b). In a similar study, Non et al. (2014) specifically investigated the degree of methylation in NR3Cl in umbilical cord blood, but were not able to replicate the abovementioned findings. However, they observe a marginally increased level of methylation at another $\mathrm{CpG}$ site within the $N R 3 C 1$ gene associated with non-medicated maternal depression or anxiety. Of note, none of the genome-wide array-based approaches referred to above found 
differences in the degree of methylation at any $\mathrm{CpG}$ sites related to this gene (Non et al., 2014). Two other studies investigated the degree of methylation at the BDNF gene, a well-known epigenetically regulated candidate gene and biomarker in mood and anxiety disorders (Boulle et al., 2012) . However, both Non and colleagues (2014), and a study by Devlin et al. (2010), found no significant associations of $B D N F$ methylation levels with antenatal mood scores or prenatal SSRI exposure. However, that same study showed that genetic variation in MTHFR, encoding for methylenetetrahydro-folate reductase, an important enzyme in the generation of methyl groups for DNA methylation, was associated with 2nd trimester depressed mood (Devlin et al., 2010). A study by Soubry et al. (2011) highlighted two imprinted differentially methylated regions (DMRs) of the IGF2 and $H 19$ gene, the latter of which requires promotor hypermethylation of the paternal allele to allow expression of the paternal allele of IGF2. Although Soubry and colleagues did not find differences in mean methylation levels when comparing umbilical cord blood of women with or without depression during pregnancy, they did observe that antidepressant exposure in African-American women was associated with a higher methylation at the H19 locus (Soubry et al., 2011). Another well-known candidate gene is SLC6A4, encoding the serotonin transporter (SERT or 5-HTT). Non and colleagues (2014) showed that SSRI exposure was associated with a slight decrease in methylation in one CpG site at the SLC6A4 locus. In addition, Devlin et al. (2010) showed that the degree of methylation at two CpG sites within the SLC6A4 promoter was lower in newborn cord blood from mothers with increased depressed mood symptoms at 26 weeks of gestation, however, this methylation had no association with SSRI exposure during pregnancy. The study by Non et al. further identified significant differential methylation in response to SSRI exposure at the NFKB2 and DNMT3a genes, while no changes were observed for CRHR1, CRHR2, DNMT1, FKBP5, NFKB1, or NFKB2. 
A recent study by Gurnot and colleagues (2015) using an array-based approach followed by a detailed candidate gene pyrosequencing approach examined neonatal DNA methylation in relation to differences in birth outcomes. They showed that lower 3rd trimester maternal depressed mood symptoms only in SSRI-exposed neonates was associated with increased cord blood DNA methylation status at $C Y P 2 E 1$, indicating a maternal mood and SSRI exposure interaction. In addition, higher DNA methylation levels at several $\mathrm{CpG}$ sites within the interrogated $C Y P 2 E 1$ region were associated with increased birth weight independently of prenatal maternal mood, SSRI drug exposure, and gestational age at birth (Gurnot et al., 2015).

\subsection{Animal Models}

Neonatal exposure to fluoxetine increased hippocampal expression of histone deacetylase 4 (HDAC4) from weaning through 18 months of age, concomitant with increased H3 and H4 acetylation at the rat HDAC4 promoter (Sarkar et al., 2014a). Interestingly, overexpression of HDAC4 was associated with increased depressive-like behaviors in postnally fluoxetine exposure offspring. This effect was reversed if HDAC4 overexpression was prevented (Sarkar et al., 2014a). reversed the behavioral effects of perinatal fluoxetine exposure in the forced swim test. Perinatal fluoxetine exposure also affects methylation, decreasing global DNA methylation in the hippocampus around weaning (Toffoli et al., 2014). Furthermore, early life exposure to paroxetine downregulated the expression of DNMT3a and the methyl-binding domain protein (MeCP) and reduced global DNA methylation in the hippocampus, but not in the amygdala, septum, nor mPFC, during the second week of life (Glover et al., 2015). As a well-known target of epigenetic regulation and a biomarker for mood-related disorders, $B D N F$ is an interesting target of investigation in these studies. Indeed, adult female Sprague-Dawley rat offspring neonatally exposed to fluoxetine and maternal stress showed altered hippocampal epigenetic 
regulation of $B D N F$ associated with increased behavioral despair (Boulle et al., 2016). More specifically, developmental SSRI exposure significantly increased behavioral despair measures on the forced swim test and decreased hippocampal BDNF exon IV mRNA levels, concomitant with increased levels of the repressive histone 3 lysine 27 tri-methylation mark at the corresponding promoter.

Future larger-sampled studies, correcting for e.g. the level of maternal depression and/or other maternal illness, and maternal use of other types of medication, could use whole genomebased sequencing to identify possible new differentially methylated sites. Understanding the role of epigenetics in mediating the effects of early-life stress and exposure to SSRIs will be of pivotal importance for development of novel therapeutic approaches.

\section{Additional Considerations}

Many of the conclusions about the effects of perinatal exposure to SSRIs have been made from studies in animal models where healthy dams and offspring were used. However, over the past few years a growing body of research has shown that perinatal SSRI effects on offspring neurobehavioral outcomes can differ when using a model of maternal stress or depression (Gemmel et al., 2015; Gemmel et al., 2016; Gobinath et al., 2016; Ishiwata et al., 2005; Ko et al., 2014; Pawluski et al., 2012b; Pawluski et al., 2015; Pawluski et al., 2012c; Pawluski et al., 2011; Rayen et al., 2015; Rayen et al., 2013b, 2014; Rayen et al., 2011). This interaction between perinatal SSRIs and maternal stress is perhaps not surprising as we know that exposure to maternal stress alone can alter the developing serotonergic system with prenatal stress increasing TPH-ir cells in the dorsal raphe nucleus (Miyagawa et al., 2011; Miyagawa et al., 2015) and increasing 5HT synthesis in the fetal brain (Peters, 1982, 1990). Thus, it is important that appropriate models of aspects of maternal mental illness be used when animal work explores 
perinatal SSRI effects on development. In this regard, it is also important that clinical research control for levels of maternal depression and anxiety in study participants prescribed, and not prescribed, SSRIs; particularly as SSRI medications often do not alleviate all aspects of maternal mental illness (Molyneaux et al., 2014) and both exposure to maternal depression and anxiety can have long-term effects on child development (Marcus, 2009; Olivier et al., 2013; Talge et al., 2007).

It is also worthwhile to consider that women are increasingly likely to continue SSRI treatment during the perinatal period if they have previously suffered from stress, anxiety and depression (which serves as one of the major risk factors for developing perinatal depression) (Pawluski et al., 2017). Therefore, future animal studies investigating the pre-gestational effects of maternal depression and SSRI exposure would be valuable to understanding the extent to which SSRIs may impact offspring development.

\section{Conclusions}

One of the strongest predictors of mental illness and behavioral disorders is early-life stress (Eiland and Romeo, 2013). However, both clinical and pre-clinical work demonstrate that offspring exposed perinatally to SSRIs, used to treat maternal stress-related disorders, may also be at risk for altered development of a host of social affiliative behaviors (Homberg et al., 2010; Man et al., 2015; Misri et al., 2006; Oberlander et al., 2010; Oberlander et al., 2007; Pawluski et al., 2012b; Rayen et al., 2013b, 2014) on a behavioral, neural and epigenetic level; these effects can be altered by maternal care as well as maternal stress and depression (Figure 1). It may be that perinatal SSRIs protect against some aspects of maternal mental illness, but also independently affect the development of social behavior-mediating neural circuitry in the hippocampus, PFC, amygdala, and hypothalamus, at a physiological, cellular, and epigenetic 
level. One of the more recently studied examples of how early-life alterations in the serotonergic environment may impact the development of social behaviors and relevant neurobiology is observed in the reported link between prenatal SSRIs and increased risk of autistic-like behaviors. More than $25 \%$ of individuals diagnosed with ASD display hyperserotonemia, which was one of the first classified clinical biomarkers indicative of the disorder (Muller et al., 2016). Individuals with ASD, as with perinatal SSRI exposure, show neurobiological and epigenetic abnormalities in all the above mentioned brain regions (Lotspeich and Ciaranello, 1993; Muller et al., 2016), as well as demonstrate increased aggressive traits which are, interestingly, often treated with medications to regulate serotonergic system functioning (Fitzpatrick et al., 2016). Therefore, it is clear that serotonin plays a critical role in regulating neurobehavioral outcomes, and in some cases may be a risk factor for the development of neurodevelopmental disorders.

Given the vital role of the serotonergic system throughout development and adulthood on a host of neurobehavioral outcomes, it is not surprising that perinatal SSRIs, which can increase serotonin levels in offspring, can have a long-term impact on neurobehavioral development. However, it should not be forgotten that exposure to maternal stress-related disorders can also alter the developing serotonergic system (Miyagawa et al., 2011; Miyagawa et al., 2015; Peters, 1982, 1990; Zohar et al., 2014) and thus more research is needed to determine the complexity of early life exposure to maternal mental illness and perinatal SSRIs on mother and child. The risks and benefits of SSRIs, as well as additional treatments for maternal affective disorders, such as psychotherapy, diet, and exercise, need further investigation and will aid in developing safe and effective treatments for both mother and child (Pawluski et al., 2017). 
Acknowledgements and Funding. The authors report no conflict of interest. JLP is presently funded by a Brain \& Behavior Foundation NARSAD Young Investigator Grant. TDC is currently funded by the Region Bretagne (SAD) and Rennes Metropole. MD is currently funded by the VEGA project 2/0168/15 (Slovak Grant Agency). MH is presently a graduate student at Duke University, USA. TFO is the R. Howard Webster Professor of Brain Imaging and Child Development, Department of Pediatrics, University of British Columbia. 


\section{Figure Captions}

Figure 1. Schematic representation of key factors influencing the development of social behavior after SSRI exposure. Present in the figure are links between maternal mood, maternal care, and SSRI medications that can all act to alter social behaviors. In addition, the age and sex/gender of the offspring are key factors mediating these effects. 


\section{References}

1. Albers, H.E., 2012. The regulation of social recognition, social communication and aggression: vasopressin in the social behavior neural network. Horm Behav 61, 283-292.

2. Alenina, N., Kikic, D., Todiras, M., Mosienko, V., Qadri, F., Plehm, R., Boye, P., Vilianovitch, L., Sohr, R., Tenner, K., Hortnagl, H., Bader, M., 2009. Growth retardation and altered autonomic control in mice lacking brain serotonin. Proc Natl Acad Sci U S A 106, 10332-10337.

3. Almond, P., 2009. Postnatal depression: a global public health perspective. Perspect Public Health 129, 221-227.

4. Andrews, M.H., Matthews, S.G., 2004. Programming of the hypothalamo-pituitary-adrenal axis: serotonergic involvement. Stress 7, 15-27.

5. Angoa-Perez, M., Kane, M.J., Sykes, C.E., Perrine, S.A., Church, M.W., Kuhn, D.M., 2014. Brain serotonin determines maternal behavior and offspring survival. Genes Brain Behav 13, 579-591.

6. Bagdy, G., 1996. Role of the hypothalamic paraventricular nucleus in 5-HT1A, 5-HT2A and 5-HT2C

receptor-mediated oxytocin, prolactin and ACTH/corticosterone responses. Behav Brain Res 73, 277-280.

7. Banerjee, S., Riordan, M., Bhat, M.A., 2014. Genetic aspects of autism spectrum disorders: insights from animal models. Frontiers in cellular neuroscience 8, 58.

8. Barofsky, A.L., Taylor, J., Tizabi, Y., Kumar, R., Jones-Quartey, K., 1983. Specific neurotoxin lesions of median raphe serotonergic neurons disrupt maternal behavior in the lactating rat. Endocrinology 113, 1884-1893.

9. Barrett, J., Fleming, A.S., 2011. Annual Research Review: All mothers are not created equal: neural and psychobiological perspectives on mothering and the importance of individual differences. J Child Psychol Psychiatry 52, 368-397.

10. Belnoue, L., Malvaut, S., Ladeveze, E., Abrous, D.N., Koehl, M., 2016. Plasticity in the olfactory bulb of the maternal mouse is prevented by gestational stress. Sci Rep 6, 37615.

11. Beversdorf, D.Q., Manning, S.E., Hillier, A., Anderson, S.L., Nordgren, R.E., Walters, S.E., Nagaraja, H.N., Cooley, W.C., Gaelic, S.E., Bauman, M.L., 2005. Timing of prenatal stressors and autism. J Autism Dev Disord 35, 471-478.

12. Bhattacharyya, A., Oppenheim, R.W., Prevette, D., Moore, B.W., Brackenbury, R., Ratner, N., 1992. S100 is present in developing chicken neurons and Schwann cells and promotes motor neuron survival in vivo. J Neurobiol 23, 451-466.

13. Boulle, F., Pawluski, J.L., Homberg, J.R., Machiels, B., Kroeze, Y., Kumar, N., Steinbusch, H.W., Kenis, G., van den Hove, D.L., 2016. Developmental fluoxetine exposure increases behavioral despair and alters epigenetic regulation of the hippocampal BDNF gene in adult female offspring. Horm Behav 80, 4757.

14. Boulle, F., van den Hove, D.L., Jakob, S.B., Rutten, B.P., Hamon, M., van Os, J., Lesch, K.P., Lanfumey, L., Steinbusch, H.W., Kenis, G., 2012. Epigenetic regulation of the BDNF gene: implications for psychiatric disorders. Mol Psychiatry 17, 584-596.

15. Brennan, P.A., Pargas, R., Walker, E.F., Green, P., Newport, D.J., Stowe, Z., 2008. Maternal

depression and infant cortisol: influences of timing, comorbidity and treatment. J Child Psychol Psychiatry 49, 1099-1107.

16. Bridges, R.S., 2015. Neuroendocrine regulation of maternal behavior. Front Neuroendocrinol 36, 178196.

17. Brummelte, S., Galea, L.A., Devlin, A.M., Oberlander, T.F., 2013. Antidepressant use during pregnancy and serotonin transporter genotype (SLC6A4) affect newborn serum reelin levels. Dev Psychobiol 55, 518-529.

18. Brummelte, S., Pawluski, J.L., Galea, L.A., 2006. High post-partum levels of corticosterone given to dams influence postnatal hippocampal cell proliferation and behavior of offspring: A model of postpartum stress and possible depression. Horm Behav 50, 370-382.

19. Burke, H.M., Davis, M.C., Otte, C., Mohr, D.C., 2005. Depression and cortisol responses to psychological stress: a meta-analysis. Psychoneuroendocrinology 30, 846-856. 
20. Cabrera-Vera, T.M., Garcia, F., Pinto, W., Battaglia, G., 1997. Effect of prenatal fluoxetine (Prozac) exposure on brain serotonin neurons in prepubescent and adult male rat offspring. J Pharmacol Exp Ther 280, 138-145.

21. Cagiano, R., Flace, P., Bera, I., Maries, L., Cioca, G., Sabatini, R., Benagiano, V., Auteri, P., Marzullo, A., Vermesan, D., Stefanelli, R., Ambrosi, G., 2008. Neurofunctional effects in rats prenatally exposed to fluoxetine. Eur Rev Med Pharmacol Sci 12, 137-148.

22. Cardoso, S.D., Teles, M.C., Oliveira, R.F., 2015. Neurogenomic mechanisms of social plasticity. J Exp Biol 218, 140-149.

23. Chalmers, D.T., Lovenberg, T.W., De Souza, E.B., 1995. Localization of novel corticotropin-releasing factor receptor (CRF2) mRNA expression to specific subcortical nuclei in rat brain: comparison with CRF1 receptor mRNA expression. J Neurosci 15, 6340-6350.

24. Champagne, F.A., 2010. Early Adversity and Developmental Outcomes: Interaction Between Genetics, Epigenetics, and Social Experiences Across the Life Span. Perspect Psychol Sci 5, 564-574.

25. Champagne, F.A., 2012. Interplay between social experiences and the genome: epigenetic consequences for behavior. Adv Genet 77, 33-57.

26. Champagne, F.A., Meaney, M.J., 2006. Stress during gestation alters postpartum maternal care and the development of the offspring in a rodent model. Biol Psychiatry 59, 1227-1235.

27. Charlton, R.A., Jordan, S., Pierini, A., Garne, E., Neville, A.J., Hansen, A.V., Gini, R., Thayer, D., Tingay, K., Puccini, A., Bos, H.J., Nybo Andersen, A.M., Sinclair, M., Dolk, H., de Jong-van den Berg, L.T., 2015. Selective serotonin reuptake inhibitor prescribing before, during and after pregnancy: a population-based study in six European regions. BJOG 122, 1010-1020.

28. Clarke, A.S., Kraemer, G.W., Kupfer, D.J., 1998. Effects of rearing condition on HPA axis response to fluoxetine and desipramine treatment over repeated social separations in young rhesus monkeys.

Psychiatry Res 79, 91-104.

29. Clements, C.C., Castro, V.M., Blumenthal, S.R., Rosenfield, H.R., Murphy, S.N., Fava, M., Erb, J.L., Churchill, S.E., Kaimal, A.J., Doyle, A.E., Robinson, E.B., Smoller, J.W., Kohane, I.S., Perlis, R.H., 2015. Prenatal antidepressant exposure is associated with risk for attention-deficit hyperactivity disorder but not autism spectrum disorder in a large health system. Mol Psychiatry 20, 727-734.

30. Cooper, W.O., Willy, M.E., Pont, S.J., Ray, W.A., 2007. Increasing use of antidepressants in pregnancy. Am J Obstet Gynecol 196, 544 e541-545.

31. Courchesne, E., Pierce, K., 2005. Why the frontal cortex in autism might be talking only to itself: local over-connectivity but long-distance disconnection. Curr Opin Neurobiol 15, 225-230.

32. Crews, D., 2010. Epigenetics, brain, behavior, and the environment. Hormones (Athens) 9, 41-50.

33. Crockett, M.J., Clark, L., Hauser, M.D., Robbins, T.W., 2010. Serotonin selectively influences moral judgment and behavior through effects on harm aversion. Proc Natl Acad Sci U S A 107, 17433-17438.

34. Dakin, C.L., Wilson, C.A., Kallo, I., Coen, C.W., Davies, D.C., 2008. Neonatal stimulation of 5-HT(2) receptors reduces androgen receptor expression in the rat anteroventral periventricular nucleus and sexually dimorphic preoptic area. Eur.J Neurosci. 27, 2473-2480.

35. Davidson, J.S., Bolland, M.J., Croxson, M.S., Chiu, W., Lewis, J.G., 2006. A case of low cortisolbinding globulin: use of plasma free cortisol in interpretation of hypothalamic-pituitary-adrenal axis tests. Ann Clin Biochem 43, 237-239.

36. Davidson, S., Prokonov, D., Taler, M., Maayan, R., Harell, D., Gil-Ad, I., Weizman, A., 2009. Effect of exposure to selective serotonin reuptake inhibitors in utero on fetal growth: potential role for the IGF-I and HPA axes. Pediatr Res 65, 236-241.

37. Devlin, A.M., Brain, U., Austin, J., Oberlander, T.F., 2010. Prenatal exposure to maternal depressed mood and the MTHFR C677T variant affect SLC6A4 methylation in infants at birth. PLoS One 5, e12201. 38. Dohler, K.D., Jarzab, B., Sickmoller, P.M., Kokocinska, D., Kaminski, M., Gubala, E., Achtelik, W., Wagiel, J., 1991. Influence of neurotransmitters on sexual differentiation of brain structure and function. Exp Clin Endocrinol 98, 99-109.

39. Dranovsky, A., Hen, R., 2006. Hippocampal neurogenesis: regulation by stress and antidepressants. Biol Psychiatry 59, 1136-1143. 
40. Eiland, L., Romeo, R.D., 2013. Stress and the developing adolescent brain. Neuroscience 249, 162171.

41. Eisch, A.J., Cameron, H.A., Encinas, J.M., Meltzer, L.A., Ming, G.L., Overstreet-Wadiche, L.S., 2008. Adult neurogenesis, mental health, and mental illness: hope or hype? J Neurosci 28, 11785-11791. 42. Eriksson, P.S., Perfilieva, E., Bjork-Eriksson, T., Alborn, A.M., Nordborg, C., Peterson, D.A., Gage, F.H., 1998. Neurogenesis in the adult human hippocampus. Nat Med 4, 1313-1317.

43. Fairbanks, L., Melega, W., McGruire, M., 1998. CSF 5-HIAA is associated with individual differences in maternal protectiveness in vervet monkeys. Am J Primatol 45, 179-180.

44. Field, T., 1995. Psychologically Depressed Parents, in: Bornstein, M. (Ed.), Handbook of Parenting. L. Erlbaum Associates, new Jersey.

45. Field, T., Healy, B., Goldstein, M., Guthertz, M., 1990. Behavior-state matching and synchrony in mother-infant interactions of nondepressed versus depressed dyads. Developmental psychobiology 26, 714.

46. Fitzpatrick, S.E., Srivorakiat, L., Wink, L.K., Pedapati, E.V., Erickson, C.A., 2016. Aggression in autism spectrum disorder: presentation and treatment options. Neuropsychiatr Dis Treat 12, 1525-1538. 47. Fleming, A.S., Ruble, D.N., Flett, G.L., Shaul, D., 1988. Postpartum Adjustment in First-Time Mothers: Relations between Mood, Maternal Attitudes and Mother-Infant Interactions'. Developmental psychobiology 24, 71-81.

48. Galea, L.A., 2008. Gonadal hormone modulation of neurogenesis in the dentate gyrus of adult male and female rodents. Brain Res Rev 57, 332-341.

49. Galea, L.A., Spritzer, M.D., Barker, J.M., Pawluski, J.L., 2006. Gonadal hormone modulation of hippocampal neurogenesis in the adult. Hippocampus 16, 225-232.

50. Gemmel, M., Rayen, I., Lotus, T., van Donkelaar, E., Steinbusch, H.W., De Lacalle, S., Kokras, N., Dalla, C., Pawluski, J.L., 2015. Developmental fluoxetine and prenatal stress effects on serotonin, dopamine, and synaptophysin density in the PFC and hippocampus of offspring at weaning. Dev Psychobiol.

51. Gemmel, M., Rayen, I., van Donkelaar, E., Loftus, T., Steinbusch, H.W., Kokras, N., Dalla, C., Pawluski, J.L., 2016. Gestational stress and fluoxetine treatment differentially affect plasticity, methylation and serotonin levels in the PFC and hippocampus of rat dams. Neuroscience 327, 32-43. 52. Glover, M.E., Clinton, S.M., 2016. Of rodents and humans: A comparative review of the neurobehavioral effects of early life SSRI exposure in preclinical and clinical research. Int J Dev Neurosci $51,50-72$.

53. Glover, M.E., Pugh, P.C., Jackson, N.L., Cohen, J.L., Fant, A.D., Akil, H., Clinton, S.M., 2015. Earlylife exposure to the SSRI paroxetine exacerbates depression-like behavior in anxiety/depression-prone rats. Neuroscience 284, 775-797.

54. Gobinath, A.R., Workman, J.L., Chow, C., Lieblich, S.E., Galea, L.A., 2016. Maternal postpartum corticosterone and fluoxetine differentially affect adult male and female offspring on anxiety-like behavior, stress reactivity, and hippocampal neurogenesis. Neuropharmacology 101, 165-178.

55. Godsil, B.P., Kiss, J.P., Spedding, M., Jay, T.M., 2013. The hippocampal-prefrontal pathway: the weak link in psychiatric disorders? Eur Neuropsychopharmacol 23, 1165-1181.

56. Gonzalez-Martinez, T., Perez-Pinera, P., Diaz-Esnal, B., Vega, J.A., 2003. S-100 proteins in the human peripheral nervous system. Microsc Res Tech 60, 633-638.

57. Gould, B.R., Zingg, H.H., 2003. Mapping oxytocin receptor gene expression in the mouse brain and mammary gland using an oxytocin receptor-LacZ reporter mouse. Neuroscience 122, 155-167.

58. Gouvea, T.S., Morimoto, H.K., de Faria, M.J., Moreira, E.G., Gerardin, D.C., 2008. Maternal exposure to the antidepressant fluoxetine impairs sexual motivation in adult male mice. Pharmacol Biochem Behav 90, 416-419.

59. Groen, W., Teluij, M., Buitelaar, J., Tendolkar, I., 2010. Amygdala and hippocampus enlargement during adolescence in autism. Journal of the American Academy of Child and Adolescent Psychiatry 49, 552-560. 
60. Gudsnuk, K., Champagne, F.A., 2012. Epigenetic influence of stress and the social environment. ILAR journal / National Research Council, Institute of Laboratory Animal Resources 53, 279-288. 61. Gurnot, C., Martin-Subero, I., Mah, S.M., Weikum, W., Goodman, S.J., Brain, U., Werker, J.F., Kobor, M.S., Esteller, M., Oberlander, T.F., Hensch, T.K., 2015. Prenatal antidepressant exposure associated with CYP2E1 DNA methylation change in neonates. Epigenetics 10, 361-372.

62. Haim, A., Albin-Brooks, C., Sherer, M., Mills, E., Leuner, B., 2015. The effects of gestational stress and SSRI antidepressant treatment on structural plasticity in the postpartum brain - A translational model for postpartum depression. Horm Behav.

63. Haim, A., Sherer, M., Leuner, B., 2014. Gestational stress induces persistent depressive-like behavior and structural modifications within the postpartum nucleus accumbens. Eur J Neurosci 40, 3766-3773. 64. Hammels, C., Prickaerts, J., Kenis, G., Vanmierlo, T., Fischer, M., Steinbusch, H.W., van Os, J., van den Hove, D.L., Rutten, B.P., 2015. Differential susceptibility to chronic social defeat stress relates to the number of Dnmt3a-immunoreactive neurons in the hippocampal dentate gyrus.

Psychoneuroendocrinology 51, 547-556.

65. Hanley, G.E., Brain, U., Oberlander, T.F., 2013. Infant developmental outcomes following prenatal exposure to antidepressants, and maternal depressed mood and positive affect. Early Hum Dev 89, 519524.

66. Hansen, S., Bergvall, A.H., Nyiredi, S., 1993. Interaction with pups enhances dopamine release in the ventral striatum of maternal rats: a microdialysis study. Pharmacol Biochem Behav 45, 673-676.

67. Harding, K.M., Lonstein, J.S., 2016. Extensive juvenile "babysitting" facilitates later adult maternal responsiveness, decreases anxiety, and increases dorsal raphe tryptophan hydroxylase-2 expression in female laboratory rats. Dev Psychobiol 58, 492-508.

68. Haring, J.H., Hagan, A., Olson, J., Rodgers, B., 1993. Hippocampal serotonin levels influence the expression of S100 beta detected by immunocytochemistry. Brain Res 631, 119-123.

69. Harris, S.S., Maciag, D., Simpson, K.L., Lin, R.C., Paul, I.A., 2012. Dose-dependent effects of neonatal SSRI exposure on adult behavior in the rat. Brain Res 1429, 52-60.

70. Hayes, R.M., Wu, P., Shelton, R.C., Cooper, W.O., Dupont, W.D., Mitchel, E., Hartert, T.V., 2012.

Maternal antidepressant use and adverse outcomes: a cohort study of 228,876 pregnancies. Am J Obstet Gynecol 207, 49 e41-49.

71. Hermansen, T.K., Roysamb, E., Augusti, E.M., Melinder, A., 2016. Behavior and inhibitory control in children with prenatal exposure to antidepressants and medically untreated depression.

Psychopharmacology (Berl) 233, 1523-1535.

72. Hillerer, K.M., Neumann, I.D., Slattery, D.A., 2012. From stress to postpartum mood and anxiety disorders: how chronic peripartum stress can impair maternal adaptations. Neuroendocrinology 95, 22-38. 73. Hitti, F.L., Siegelbaum, S.A., 2014. The hippocampal CA2 region is essential for social memory. Nature 508, 88-92.

74. Holschbach, M.A., Lonstein, J.S., 2016. Motherhood and infant contact regulate neuroplasticity in the serotonergic midbrain dorsal raphe. Psychoneuroendocrinology 76, 97-106.

75. Holschbach, M.A., Lonstein, J.S., 2017. Motherhood and infant contact regulate neuroplasticity in the serotonergic midbrain dorsal raphe. Psychoneuroendocrinology 76, 97-106.

76. Homberg, J.R., Schiepers, O.J., Schoffelmeer, A.N., Cuppen, E., Vanderschuren, L.J., 2007. Acute and constitutive increases in central serotonin levels reduce social play behaviour in peri-adolescent rats. Psychopharmacology (Berl) 195, 175-182.

77. Homberg, J.R., Schubert, D., Gaspar, P., 2010. New perspectives on the neurodevelopmental effects of SSRIs. Trends Pharmacol Sci 31, 60-65.

78. Huizink, A.C., Robles de Medina, P.G., Mulder, E.J., Visser, G.H., Buitelaar, J.K., 2003. Stress during pregnancy is associated with developmental outcome in infancy. J Child Psychol Psychiatry 44, 810-818.

79. Ishiwata, H., Shiga, T., Okado, N., 2005. Selective serotonin reuptake inhibitor treatment of early postnatal mice reverses their prenatal stress-induced brain dysfunction. Neuroscience 133, 893-901. 
80. Ito, H., Shimogawa, Y., Kohagura, D., Moriizumi, T., Yamanouchi, K., 2014. Inhibitory role of the serotonergic system on estrogen receptor alpha expression in the female rat hypothalamus. Neurosci Lett 583, 194-198.

81. Jarzab, B., Dohler, K.D., 1984. Serotoninergic influences on sexual differentiation of the rat brain. Prog.Brain Res. 61, 119-126.

82. Jin, J., Maren, S., 2015. Prefrontal-Hippocampal Interactions in Memory and Emotion. Front Syst Neurosci 9, 170.

83. Johns, J.M., Joyner, P.W., McMurray, M.S., Elliott, D.L., Hofler, V.E., Middleton, C.L., Knupp, K., Greenhill, K.W., Lomas, L.M., Walker, C.H., 2005. The effects of dopaminergic/serotonergic reuptake inhibition on maternal behavior, maternal aggression, and oxytocin in the rat. Pharmacol Biochem Behav 81, 769-785.

84. Johnson, K.C., Smith, A.K., Stowe, Z.N., Newport, D.J., Brennan, P.A., 2016. Preschool outcomes following prenatal serotonin reuptake inhibitor exposure: differences in language and behavior, but not cognitive function. J Clin Psychiatry 77, e176-182.

85. Jorgensen, H., Riis, M., Knigge, U., Kjaer, A., Warberg, J., 2003. Serotonin receptors involved in vasopressin and oxytocin secretion. J Neuroendocrinol 15, 242-249.

86. Kaldewaij, R., Koch, S.B., Volman, I., Toni, I., Roelofs, K., 2016. On the Control of Social ApproachAvoidance Behavior: Neural and Endocrine Mechanisms. Curr Top Behav Neurosci.

87. Karpova, N.N., Lindholm, J., Pruunsild, P., Timmusk, T., Castren, E., 2009. Long-lasting behavioural and molecular alterations induced by early postnatal fluoxetine exposure are restored by chronic

fluoxetine treatment in adult mice. Eur Neuropsychopharmacol 19, 97-108.

88. Keer, S.E., Stern, J.M., 1999. Dopamine receptor blockade in the nucleus accumbens inhibits maternal retrieval and licking, but enhances nursing behavior in lactating rats. Physiol Behav 67, 659-669.

89. Keverne, E.B., Curley, J.P., 2008. Epigenetics, brain evolution and behaviour. Front Neuroendocrinol 29, 398-412.

90. Khatri, N., Simpson, K.L., Lin, R.C., Paul, I.A., 2014. Lasting neurobehavioral abnormalities in rats after neonatal activation of serotonin 1A and 1B receptors: possible mechanisms for serotonin dysfunction in autistic spectrum disorders. Psychopharmacology (Berl) 231, 1191-1200.

91. Kigar, S.L., Auger, A.P., 2013. Epigenetic mechanisms may underlie the aetiology of sex differences in mental health risk and resilience. Journal of neuroendocrinology 25, 1141-1150.

92. Kim, D.R., Epperson, C.N., Weiss, A.R., Wisner, K.L., 2014. Pharmacotherapy of postpartum depression: an update. Expert Opin Pharmacother 15, 1223-1234.

93. Kiryanova, V., Dyck, R.H., 2014. Increased aggression, improved spatial memory, and reduced anxiety-like behaviour in adult male mice exposed to fluoxetine early in life. Dev Neurosci 36, 396-408. 94. Kiryanova, V., Meunier, S.J., Vecchiarelli, H.A., Hill, M.N., Dyck, R.H., 2016. Effects of maternal stress and perinatal fluoxetine exposure on behavioral outcomes of adult male offspring. Neuroscience 320, 281-296.

95. Kiser, D., Steemers, B., Branchi, I., Homberg, J.R., 2012. The reciprocal interaction between serotonin and social behaviour. Neurosci Biobehav Rev 36, 786-798.

96. Knaepen, L., Pawluski, J.L., Patijn, J., van Kleef, M., Tibboel, D., Joosten, E.A., 2013. Perinatal maternal stress and serotonin signaling: Effects on pain sensitivity in offspring. Dev Psychobiol.

97. Ko, M.C., Lee, L.J., Li, Y., Lee, L.J., 2014. Long-term consequences of neonatal fluoxetine exposure in adult rats. Dev Neurobiol 74, 1038-1051.

98. Kobayashi, T., Matsuyama, T., Takeuchi, M., Ito, S., 2016. Autism spectrum disorder and prenatal exposure to selective serotonin reuptake inhibitors: A systematic review and meta-analysis. Reprod Toxicol 65, 170-178.

99. Kyriacou, D.N., Lewis, R.J., 2016. Confounding by Indication in Clinical Research. JAMA 316, 18181819.

100. Laplante, D.P., Barr, R.G., Brunet, A., Galbaud du Fort, G., Meaney, M.L., Saucier, J.F., Zelazo, P.R., King, S., 2004. Stress during pregnancy affects general intellectual and language functioning in human toddlers. Pediatr Res 56, 400-410. 
101. Laplante, P., Diorio, J., Meaney, M.J., 2002. Serotonin regulates hippocampal glucocorticoid receptor expression via a 5-HT7 receptor. Brain Res Dev Brain Res 139, 199-203.

102. Lee, H.J., Kim, J.W., Yim, S.V., Kim, M.J., Kim, S.A., Kim, Y.J., Kim, C.J., Chung, J.H., 2001.

Fluoxetine enhances cell proliferation and prevents apoptosis in dentate gyrus of maternally separated rats. Mol Psychiatry 6, 610, 725-618.

103. Lee, L.J., 2009. Neonatal fluoxetine exposure affects the neuronal structure in the somatosensory cortex and somatosensory-related behaviors in adolescent rats. Neurotox Res 15, 212-223.

104. Lee, L.J., Lee, L.J., 2012. Neonatal fluoxetine exposure alters motor performances of adolescent rats. Dev Neurobiol 72, 1122-1132.

105. Lerch-Haner, J.K., Frierson, D., Crawford, L.K., Beck, S.G., Deneris, E.S., 2008. Serotonergic transcriptional programming determines maternal behavior and offspring survival. Nat Neurosci 11, 10011003.

106. Lesch, K.P., Araragi, N., Waider, J., van den Hove, D., Gutknecht, L., 2012. Targeting brain serotonin synthesis: insights into neurodevelopmental disorders with long-term outcomes related to negative emotionality, aggression and antisocial behaviour. Philos Trans R Soc Lond B Biol Sci 367, 2426-2443.

107. Leuner, B., Fredericks, P.J., Nealer, C., Albin-Brooks, C., 2014. Chronic gestational stress leads to depressive-like behavior and compromises medial prefrontal cortex structure and function during the postpartum period. PLoS One 9, e89912.

108. Leuner, B., Glasper, E.R., Gould, E., 2010. Sexual experience promotes adult neurogenesis in the hippocampus despite an initial elevation in stress hormones. PLoS One 5, e11597.

109. Leung, B.M., Kaplan, B.J., 2009. Perinatal depression: prevalence, risks, and the nutrition link--a review of the literature. Journal of the American Dietetic Association 109, 1566-1575.

110. Liao, C.C., Lee, L.J., 2011. Neonatal fluoxetine exposure affects the action potential properties and dendritic development in cortical subplate neurons of rats. Toxicol Lett 207, 314-321.

111. Lindell, S., Higley, J., Shannon, C., Linnoila, M., 1997. Low levels of CSF 5-HIAA in female rhesus macaques predict mother-infant interaction patterns and mother's CSF 5-HIAA correlates with infant's CSF 5-HIAA. Am J Primatol 42, 129.

112. Lonstein, J.S., Dominguez, J.M., Putnam, S.K., De Vries, G.J., Hull, E.M., 2003. Intracellular preoptic and striatal monoamines in pregnant and lactating rats: possible role in maternal behavior. Brain Res 970, 149-158.

113. Lonstein, J.S., Maguire, J., Meinlschmidt, G., Neumann, I.D., 2014. Emotion and mood adaptations in the peripartum female:complementary contributions of GABA and oxytocin. J Neuroendocrinol 26, 649-664.

114. Lonstein, J.S., Wagner, C.K., De Vries, G.J., 1999. Comparison of the "nursing" and other parental behaviors of nulliparous and lactating female rats. Horm Behav 36, 242-251.

115. Lotspeich, L.J., Ciaranello, R.D., 1993. The neurobiology and genetics of infantile autism. Int Rev Neurobiol 35, 87-129.

116. Lupattelli, A., Spigset, O., Twigg, M.J., Zagorodnikova, K., Mardby, A.C., Moretti, M.E., Drozd, M., Panchaud, A., Hameen-Anttila, K., Rieutord, A., Gjergja Juraski, R., Odalovic, M., Kennedy, D., Rudolf, G., Juch, H., Passier, A., Bjornsdottir, I., Nordeng, H., 2014. Medication use in pregnancy: a crosssectional, multinational web-based study. BMJ Open 4, e004365.

117. Maccari, S., Krugers, H.J., Morley-Fletcher, S., Szyf, M., Brunton, P.J., 2014. The consequences of early-life adversity: neurobiological, behavioural and epigenetic adaptations. J Neuroendocrinol 26, 707723.

118. Maciag, D., Coppinger, D., Paul, I.A., 2006a. Evidence that the deficit in sexual behavior in adult rats neonatally exposed to citalopram is a consequence of 5-HT1 receptor stimulation during development.

Brain Res 1125, 171-175.

119. Maciag, D., Simpson, K.L., Coppinger, D., Lu, Y., Wang, Y., Lin, R.C., Paul, I.A., 2006b. Neonatal antidepressant exposure has lasting effects on behavior and serotonin circuitry.

Neuropsychopharmacology 31, 47-57. 
120. Maciag, D., Williams, L., Coppinger, D., Paul, I.A., 2006c. Neonatal citalopram exposure produces lasting changes in behavior which are reversed by adult imipramine treatment. Eur J Pharmacol 532, 265269.

121. Man, K.K., Tong, H.H., Wong, L.Y., Chan, E.W., Simonoff, E., Wong, I.C., 2015. Exposure to selective serotonin reuptake inhibitors during pregnancy and risk of autism spectrum disorder in children: a systematic review and meta-analysis of observational studies. Neurosci Biobehav Rev 49, 82-89.

122. Marcus, S.M., 2009. Depression during pregnancy: rates, risks and consequences--Motherisk Update 2008. The Canadian journal of clinical pharmacology = Journal canadien de pharmacologie clinique 16, e15-22.

123. Maren, S., Phan, K.L., Liberzon, I., 2013. The contextual brain: implications for fear conditioning, extinction and psychopathology. Nat Rev Neurosci 14, 417-428.

124. McEwen, B.S., 2005. Glucocorticoids, depression, and mood disorders: structural remodeling in the brain. Metabolism 54, 20-23.

125. McGowan, P.O., Szyf, M., 2010. The epigenetics of social adversity in early life: implications for mental health outcomes. Neurobiol Dis 39, 66-72.

126. McNamara, I.M., Borella, A.W., Bialowas, L.A., Whitaker-Azmitia, P.M., 2008. Further studies in the developmental hyperserotonemia model (DHS) of autism: social, behavioral and peptide changes.

Brain Res 1189, 203-214.

127. Meaney, M.J., 2001. Maternal care, gene expression, and the transmission of individual differences in stress reactivity across generations. Annu Rev Neurosci 24, 1161-1192.

128. Meaney, M.J., Diorio, J., Francis, D., LaRocque, S., O'Donnell, D., Smythe, J.W., Sharma, S.,

Tannenbaum, B., 1994. Environmental regulation of the development of glucocorticoid receptor systems in the rat forebrain. The role of serotonin. Ann N Y Acad Sci 746, 260-273; discussion 274, 289-293.

129. Mileva-Seitz, V., Kennedy, J., Atkinson, L., Steiner, M., Levitan, R., Matthews, S.G., Meaney, M.J., Sokolowski, M.B., Fleming, A.S., 2011. Serotonin transporter allelic variation in mothers predicts maternal sensitivity, behavior and attitudes toward 6-month-old infants. Genes Brain Behav 10, 325-333. 130. Mirmiran, M., van de Poll, N.E., Corner, M.A., van Oyen, H.G., Bour, H.L., 1981. Suppression of active sleep by chronic treatment with chlorimipramine during early postnatal development: effects upon adult sleep and behavior in the rat. Brain Res. 204, 129-146.

131. Misri, S., Kostaras, X., 2002. Benefits and risks to mother and infant of drug treatment for postnatal depression. Drug Saf 25, 903-911.

132. Misri, S., Reebye, P., Corral, M., Milis, L., 2004. The use of paroxetine and cognitive-behavioral therapy in postpartum depression and anxiety: a randomized controlled trial. J Clin Psychiatry 65, 12361241.

133. Misri, S., Reebye, P., Kendrick, K., Carter, D., Ryan, D., Grunau, R.E., Oberlander, T.F., 2006.

Internalizing behaviors in 4-year-old children exposed in utero to psychotropic medications. The American journal of psychiatry 163, 1026-1032.

134. Miyagawa, K., Tsuji, M., Fujimori, K., Saito, Y., Takeda, H., 2011. Prenatal stress induces anxietylike behavior together with the disruption of central serotonin neurons in mice. Neuroscience research 70 , 111-117.

135. Miyagawa, K., Tsuji, M., Ishii, D., Takeda, K., Takeda, H., 2015. Prenatal stress induces

vulnerability to stress together with the disruption of central serotonin neurons in mice. Behav Brain Res 277, 228-236.

136. Molyneaux, E., Howard, L.M., McGeown, H.R., Karia, A.M., Trevillion, K., 2014. Antidepressant treatment for postnatal depression. Cochrane Database Syst Rev, CD002018.

137. Morrison, J.L., Riggs, K.W., Chien, C., Gruber, N., McMillen, I.C., Rurak, D.W., 2004. Chronic maternal fluoxetine infusion in pregnant sheep: effects on the maternal and fetal hypothalamic-pituitaryadrenal axes. Pediatr Res 56, 40-46.

138. Muller, C.L., Anacker, A.M., Veenstra-VanderWeele, J., 2016. The serotonin system in autism spectrum disorder: From biomarker to animal models. Neuroscience 321, 24-41. 
139. Nagano, M., Liu, M., Inagaki, H., Kawada, T., Suzuki, H., 2012. Early intervention with fluoxetine reverses abnormalities in the serotonergic system and behavior of rats exposed prenatally to dexamethasone. Neuropharmacology 63, 292-300.

140. Non, A.L., Binder, A.M., Kubzansky, L.D., Michels, K.B., 2014. Genome-wide DNA methylation in neonates exposed to maternal depression, anxiety, or SSRI medication during pregnancy. Epigenetics 9, 964-972.

141. Numan, M., Fleming, A.S., Levy, F., 2006. Maternal Behavior, in: Neill, J.D. (Ed.), Physiology of Reproduction, 3 ed. Elsevier, New York, NY, pp. 1921-1993.

142. O'Donnell, K.A., Gaudreau, H., Colalillo, S., Steiner, M., Atkinson, L., Moss, E., Goldberg, S., Karama, S., Matthews, S.G., Lydon, J.E., Silveira, P.P., Wazana, A.D., Levitan, R.D., Sokolowski, M.B., Kennedy, J.L., Fleming, A., Meaney, M.J., Team, M.R., 2014. The maternal adversity, vulnerability and neurodevelopment project: theory and methodology. Can J Psychiatry 59, 497-508.

143. Oberlander, T.F., Eckstein Grunau, R., Fitzgerald, C., Ellwood, A.L., Misri, S., Rurak, D., Riggs, K.W., 2002. Prolonged prenatal psychotropic medication exposure alters neonatal acute pain response. Pediatric research 51, 443-453.

144. Oberlander, T.F., Gingrich, J.A., Ansorge, M.S., 2009. Sustained neurobehavioral effects of exposure to SSRI antidepressants during development: molecular to clinical evidence. Clin Pharmacol Ther 86, 672-677.

145. Oberlander, T.F., Grunau, R., Mayes, L., Riggs, W., Rurak, D., Papsdorf, M., Misri, S., Weinberg, J., 2008a. Hypothalamic-pituitary-adrenal (HPA) axis function in 3-month old infants with prenatal selective serotonin reuptake inhibitor (SSRI) antidepressant exposure. Early Hum Dev.

146. Oberlander, T.F., Grunau, R.E., Fitzgerald, C., Papsdorf, M., Rurak, D., Riggs, W., 2005. Pain

reactivity in 2-month-old infants after prenatal and postnatal serotonin reuptake inhibitor medication exposure. Pediatrics 115, 411-425.

147. Oberlander, T.F., Papsdorf, M., Brain, U.M., Misri, S., Ross, C., Grunau, R.E., 2010. Prenatal effects of selective serotonin reuptake inhibitor antidepressants, serotonin transporter promoter genotype

(SLC6A4), and maternal mood on child behavior at 3 years of age. Arch Pediatr Adolesc Med 164, 444451.

148. Oberlander, T.F., Reebye, P., Misri, S., Papsdorf, M., Kim, J., Grunau, R.E., 2007. Externalizing and attentional behaviors in children of depressed mothers treated with a selective serotonin reuptake inhibitor antidepressant during pregnancy. Arch Pediatr Adolesc Med 161, 22-29.

149. Oberlander, T.F., Warburton, W., Misri, S., Aghajanian, J., Hertzman, C., 2006. Neonatal outcomes after prenatal exposure to selective serotonin reuptake inhibitor antidepressants and maternal depression using population-based linked health data. Arch Gen Psychiatry 63, 898-906.

150. Oberlander, T.F., Weinberg, J., Papsdorf, M., Grunau, R., Misri, S., Devlin, A.M., 2008b. Prenatal exposure to maternal depression, neonatal methylation of human glucocorticoid receptor gene (NR3C1) and infant cortisol stress responses. Epigenetics 3, 97-106.

151. Olivier, J.D., Akerud, H., Kaihola, H., Pawluski, J.L., Skalkidou, A., Hogberg, U., Sundstrom-

Poromaa, I., 2013. The effects of maternal depression and maternal selective serotonin reuptake inhibitor exposure on offspring. Front Cell Neurosci 7, 73.

152. Olivier, J.D., Valles, A., van Heesch, F., Afrasiab-Middelman, A., Roelofs, J.J., Jonkers, M., Peeters, E.J., Korte-Bouws, G.A., Dederen, J.P., Kiliaan, A.J., Martens, G.J., Schubert, D., Homberg, J.R., 2011 a.

Fluoxetine administration to pregnant rats increases anxiety-related behavior in the offspring.

Psychopharmacology (Berl) 217, 419-432.

153. Olivier, J.D., Valles, A., van Heesch, F., Afrasiab-Middelman, A., Roelofs, J.J., Jonkers, M., Peeters, E.J., Korte-Bouws, G.A., Dederen, J.P., Kiliaan, A.J., Martens, G.J., Schubert, D., Homberg, J.R., 2011 b.

Fluoxetine administration to pregnant rats increases anxiety-related behavior in the offspring.

Psychopharmacology (Berl).

154. Patchev, A.V., Rodrigues, A.J., Sousa, N., Spengler, D., Almeida, O.F., 2014. The future is now:

early life events preset adult behaviour. Acta Physiol (Oxf) 210, 46-57. 
155. Pawluski, J., JS, L., AS, F., 2017. The Neurobiology of Postpartum Anxiety and Depression. Trends in Neurosciences.

156. Pawluski, J.L., Brain, U.M., Underhill, C.M., Hammond, G.L., Oberlander, T.F., 2012a. Prenatal SSRI exposure alters neonatal corticosteroid binding globulin, infant cortisol levels, and emerging HPA function. Psychoneuroendocrinology 37, 1019-1028.

157. Pawluski, J.L., Brummelte, S., Barha, C.K., Crozier, T.M., Galea, L.A., 2009a. Effects of steroid hormones on neurogenesis in the hippocampus of the adult female rodent during the estrous cycle, pregnancy, lactation and aging. Front Neuroendocrinol 30, 343-357.

158. Pawluski, J.L., Charlier, T.D., Fillet, M., Houbart, V., Crispin, H.T., Steinbusch, H.W., van den Hove, D.L., 2012b. Chronic fluoxetine treatment and maternal adversity differentially alter neurobehavioral outcomes in the rat dam. Behav Brain Res 228, 159-168.

159. Pawluski, J.L., Galea, L.A., Brain, U., Papsdorf, M., Oberlander, T.F., 2009b. Neonatal S100B protein levels after prenatal exposure to selective serotonin reuptake inhibitors. Pediatrics 124, e662-670. 160. Pawluski, J.L., Gemmel, M., Császár, E., Steinbusch, H.W., Rayen, I., 2015. Developmental Fluoxetine Exposure and Neuroendocrine Outcomes, in: Pinna, G. (Ed.), Fluoxetine: Pharmacology, Mechanisms of Action and Potential Side Effects. Nova Science Publishers, New York, NY, pp. 43-70. 161. Pawluski, J.L., Rayen, I., Niessen, N.A., Kristensen, S., van Donkelaar, E.L., Balthazart, J., Steinbusch, H.W., Charlier, T.D., 2012c. Developmental fluoxetine exposure differentially alters central and peripheral measures of the HPA system in adolescent male and female offspring. Neuroscience 220, 131-141.

162. Pawluski, J.L., van den Hove, D.L., Rayen, I., Prickaerts, J., Steinbusch, H.W., 2011. Stress and the pregnant female: Impact on hippocampal cell proliferation, but not affective-like behaviors. Horm Behav 59, 572-580.

163. Peters, D.A., 1982. Prenatal stress: effects on brain biogenic amine and plasma corticosterone levels. Pharmacol Biochem Behav 17, 721-725.

164. Peters, D.A., 1990. Maternal stress increases fetal brain and neonatal cerebral cortex 5-

hydroxytryptamine synthesis in rats: a possible mechanism by which stress influences brain development. Pharmacol Biochem Behav 35, 943-947.

165. Pinna, G., 2015. Fluoxetine : pharmacology, mechanisms of action and potential side effects. Nova

Science Publishers, Hauppauge, NY.

166. Podrebarac, S.K., Duerden, E.G., Chau, V., Grunau, R.E., Synnes, A., Oberlander, T.F., Miller, S.P., 2016. Antenatal exposure to antidepressants is associated with altered brain development in very pretermborn neonates. Neuroscience.

167. Provencal, N., Binder, E.B., 2015. The effects of early life stress on the epigenome: From the womb to adulthood and even before. Exp Neurol 268, 10-20.

168. Ragan, C.M., Harding, K.M., Lonstein, J.S., 2016. Associations among within-litter differences in early mothering received and later emotional behaviors, mothering, and cortical tryptophan hydroxylase-2 expression in female laboratory rats. Horm Behav 77, 62-71.

169. Ravi, B., Kannan, M., 2013. Epigenetics in the nervous system: An overview of its essential role.

Indian J Hum Genet 19, 384-391.

170. Rayen, I., Gemmel, M., Pauley, G., Steinbusch, H.W., Pawluski, J.L., 2015. Developmental exposure to SSRIs, in addition to maternal stress, has long-term sex-dependent effects on hippocampal plasticity. Psychopharmacology (Berl) 232, 1231-1244.

171. Rayen, I., Steinbusch, H.W., Charlier, T.D., Pawluski, J.L., 2013a. Developmental fluoxetine exposure and prenatal stress alter sexual differentiation of the brain and reproductive behavior in male rat offspring. Psychoneuroendocrinology.

172. Rayen, I., Steinbusch, H.W., Charlier, T.D., Pawluski, J.L., 2013b. Developmental fluoxetine exposure and prenatal stress alter sexual differentiation of the brain and reproductive behavior in male rat offspring. Psychoneuroendocrinology 38, 1618-1629.

173. Rayen, I., Steinbusch, H.W., Charlier, T.D., Pawluski, J.L., 2014. Developmental fluoxetine exposure facilitates sexual behavior in female offspring. Psychopharmacology (Berl) 231, 123-133. 
174. Rayen, I., van den Hove, D.L., Prickaerts, J., Steinbusch, H.W., Pawluski, J.L., 2011. Fluoxetine during development reverses the effects of prenatal stress on depressive-like behavior and hippocampal neurogenesis in adolescence. PLoS One 6, e24003.

175. Rifkin-Graboi, A., Kong, L., Sim, L.W., Sanmugam, S., Broekman, B.F., Chen, H., Wong, E., Kwek, K., Saw, S.M., Chong, Y.S., Gluckman, P.D., Fortier, M.V., Pederson, D., Meaney, M.J., Qiu, A., 2015. Maternal sensitivity, infant limbic structure volume and functional connectivity: a preliminary study. Transl Psychiatry 5, e668.

176. Rodriguez-Porcel, F., Green, D., Khatri, N., Harris, S.S., May, W.L., Lin, R.C., Paul, I.A., 2011. Neonatal exposure of rats to antidepressants affects behavioral reactions to novelty and social interactions in a manner analogous to autistic spectrum disorders. Anat Rec (Hoboken) 294, 1726-1735.

177. Rosenblatt, J.S., 1969. The development of maternal responsiveness in the rat. Am J Orthopsychiatry 39, 36-56.

178. Santarelli, L., Saxe, M., Gross, C., Surget, A., Battaglia, F., Dulawa, S., Weisstaub, N., Lee, J., Duman, R., Arancio, O., Belzung, C., Hen, R., 2003. Requirement of hippocampal neurogenesis for the behavioral effects of antidepressants. Science 301, 805-809.

179. Sarkar, A., Chachra, P., Kennedy, P., Pena, C.J., Desouza, L.A., Nestler, E.J., Vaidya, V.A., 2014a. Hippocampal HDAC4 contributes to postnatal fluoxetine-evoked depression-like behavior.

Neuropsychopharmacology 39, 2221-2232.

180. Sarkar, A., Chachra, P., Vaidya, V.A., 2014b. Postnatal fluoxetine-evoked anxiety is prevented by concomitant $5-\mathrm{HT} 2 \mathrm{~A} / \mathrm{C}$ receptor blockade and mimicked by postnatal $5-\mathrm{HT} 2 \mathrm{~A} / \mathrm{C}$ receptor stimulation. Biol Psychiatry 76, 858-868.

181. Sato, T., Matsumoto, T., Kawano, H., Watanabe, T., Uematsu, Y., Sekine, K., Fukuda, T., Aihara, K., Krust, A., Yamada, T., Nakamichi, Y., Yamamoto, Y., Nakamura, T., Yoshimura, K., Yoshizawa, T., Metzger, D., Chambon, P., Kato, S., 2004. Brain masculinization requires androgen receptor function. Proc Natl Acad Sci U S A 101, 1673-1678.

182. Sekino, Y., Obata, K., Tanifuji, M., Mizuno, M., Murayama, J., 1997. Delayed signal propagation via CA2 in rat hippocampal slices revealed by optical recording. J Neurophysiol 78, 1662-1668.

183. Selinfreund, R.H., Barger, S.W., Pledger, W.J., Van Eldik, L.J., 1991. Neurotrophic protein S100 beta stimulates glial cell proliferation. Proc Natl Acad Sci U S A 88, 3554-3558.

184. Shiba, Y., Santangelo, A.M., Roberts, A.C., 2016. Beyond the Medial Regions of Prefrontal Cortex in the Regulation of Fear and Anxiety. Front Syst Neurosci 10, 12.

185. Sigurdsson, T., Stark, K.L., Karayiorgou, M., Gogos, J.A., Gordon, J.A., 2010. Impaired hippocampal-prefrontal synchrony in a genetic mouse model of schizophrenia. Nature 464, 763-767. 186. Simpson, K.L., Weaver, K.J., de Villers-Sidani, E., Lu, J.Y., Cai, Z., Pang, Y., Rodriguez-Porcel, F., Paul, I.A., Merzenich, M., Lin, R.C., 2011. Perinatal antidepressant exposure alters cortical network function in rodents. Proc Natl Acad Sci U S A 108, 18465-18470.

187. Smit-Rigter, L.A., Noorlander, C.W., von Oerthel, L., Chameau, P., Smidt, M.P., van Hooft, J.A., 2012. Prenatal fluoxetine exposure induces life-long serotonin 5-HT(3) receptor-dependent cortical abnormalities and anxiety-like behaviour. Neuropharmacology 62, 865-870.

188. Smith, C.D., Piasecki, C.C., Weera, M., Olszewicz, J., Lonstein, J.S., 2013. Noradrenergic alpha-2 receptor modulators in the ventral bed nucleus of the stria terminalis: effects on anxiety behavior in postpartum and virgin female rats. Behav Neurosci 127, 582-597.

189. Soga, T., Wong, D.W., Putteeraj, M., Song, K.P., Parhar, I.S., 2012. Early-life citalopram-induced impairments in sexual behavior and the role of androgen receptor. Neuroscience 225, 172-184.

190. Soubry, A., Murphy, S., Huang, Z., Murtha, A., Schildkraut, J., Jirtle, R., Wang, F., Kurtzberg, J., Demark-Wahnefried, W., Forman, M., Hoyo, C., 2011. The effects of depression and use of antidepressive medicines during pregnancy on the methylation status of the IGF2 imprinted control regions in the offspring. Clin Epigenetics 3, 2.

191. Stamatakis, A., Kalpachidou, T., Raftogianni, A., Zografou, E., Tzanou, A., Pondiki, S., Stylianopoulou, F., 2015. Rat dams exposed repeatedly to a daily brief separation from the pups exhibit 
increased maternal behavior, decreased anxiety and altered levels of receptors for estrogens (ERalpha, ERbeta), oxytocin and serotonin (5-HT1A) in their brain. Psychoneuroendocrinology 52, 212-228.

192. Steinbusch, H.W., 1981. Distribution of serotonin-immunoreactivity in the central nervous system of the rat-cell bodies and terminals. Neuroscience 6, 557-618.

193. Stevenson, E.L., Caldwell, H.K., 2014. Lesions to the CA2 region of the hippocampus impair social memory in mice. Eur J Neurosci 40, 3294-3301.

194. Svirsky, N., Levy, S., Avitsur, R., 2016. Prenatal exposure to selective serotonin reuptake inhibitors (SSRI) increases aggression and modulates maternal behavior in offspring mice. Dev Psychobiol 58, 7182.

195. Svrakic, D.M., Cloninger, R.C., 2010. Epigenetic perspective on behavior development, personality, and personality disorders. Psychiatr Danub 22, 153-166.

196. Szyf, M., 2011. The early life social environment and DNA methylation: DNA methylation mediating the long-term impact of social environments early in life. Epigenetics 6, 971-978.

197. Szyf, M., 2013. DNA methylation, behavior and early life adversity. J Genet Genomics 40, 331-338.

198. Tabori, N.E., Stewart, L.S., Znamensky, V., Romeo, R.D., Alves, S.E., McEwen, B.S., Milner, T.A., 2005. Ultrastructural evidence that androgen receptors are located at extranuclear sites in the rat hippocampal formation. Neuroscience 130, 151-163.

199. Talge, N.M., Neal, C., Glover, V., Early Stress, T.R., Prevention Science Network, F., Neonatal

Experience on, C., Adolescent Mental, H., 2007. Antenatal maternal stress and long-term effects on child neurodevelopment: how and why? J Child Psychol Psychiatry 48, 245-261.

200. Toffoli, L.V., Rodrigues, G.M., Jr., Oliveira, J.F., Silva, A.S., Moreira, E.G., Pelosi, G.G., Gomes, M.V., 2014. Maternal exposure to fluoxetine during gestation and lactation affects the DNA methylation programming of rat's offspring: modulation by folic acid supplementation. Behav Brain Res 265, 142-147. 201. Tonissaar, M., Philips, M.A., Eller, M., Harro, J., 2004. Sociability trait and serotonin metabolism in the rat social interaction test. Neurosci Lett 367, 309-312.

202. Van den Bergh, B.R., Mennes, M., Oosterlaan, J., Stevens, V., Stiers, P., Marcoen, A., Lagae, L., 2005. High antenatal maternal anxiety is related to impulsivity during performance on cognitive tasks in 14- and 15-year-olds. Neurosci Biobehav Rev 29, 259-269.

203. Van den Bergh, B.R., Van Calster, B., Smits, T., Van Huffel, S., Lagae, L., 2008. Antenatal maternal anxiety is related to HPA-axis dysregulation and self-reported depressive symptoms in adolescence: a prospective study on the fetal origins of depressed mood. Neuropsychopharmacology 33, 536-545. 204. Vialou, V., Feng, J., Robison, A.J., Nestler, E.J., 2013. Epigenetic mechanisms of depression and antidepressant action. Annu Rev Pharmacol Toxicol 53, 59-87.

205. Viuff, A.C., Pedersen, L.H., Kyng, K., Staunstrup, N.H., Borglum, A., Henriksen, T.B., 2016.

Antidepressant medication during pregnancy and epigenetic changes in umbilical cord blood: a systematic review. Clin Epigenetics 8, 94.

206. Vogel, G., Neill, D., Hagler, M., Kors, D., 1990. A new animal model of endogenous depression: a summary of present findings. Neurosci Biobehav Rev 14, 85-91.

207. Wazana, A., Moss, E., Jolicoeur-Martineau, A., Graffi, J., Tsabari, G., Lecompte, V., Pascuzzo, K., Babineau, V., Gordon-Green, C., Mileva, V., Atkinson, L., Minde, K., Bouvette-Turcot, A.A., Sassi, R., St-Andre, M., Carrey, N., Matthews, S., Sokolowski, M., Lydon, J., Gaudreau, H., Steiner, M., Kennedy, J.L., Fleming, A., Levitan, R., Meaney, M.J., 2015. The interplay of birth weight, dopamine receptor D4 gene (DRD4), and early maternal care in the prediction of disorganized attachment at 36 months of age. Dev Psychopathol 27, 1145-1161.

208. Weaver, K.J., Paul, I.A., Lin, R.C., Simpson, K.L., 2010. Neonatal exposure to citalopram selectively alters the expression of the serotonin transporter in the hippocampus: dose-dependent effects. Anat Rec (Hoboken) 293, 1920-1932.

209. Weikum, W.M., Mayes, L.C., Grunau, R.E., Brain, U., Oberlander, T.F., 2013. The impact of prenatal serotonin reuptake inhibitor (SRI) antidepressant exposure and maternal mood on mother-infant interactions at 3 months of age. Infant Behav Dev 36, 485-493. 
210. Weiland, N.G., Orikasa, C., Hayashi, S., McEwen, B.S., 1997. Distribution and hormone regulation of estrogen receptor immunoreactive cells in the hippocampus of male and female rats. J Comp Neurol 388, 603-612.

211. Whitaker-Azmitia, P.M., 2001. Serotonin and brain development: role in human developmental diseases. Brain Res Bull 56, 479-485.

212. Whitaker-Azmitia, P.M., Murphy, R., Azmitia, E.C., 1990. Stimulation of astroglial 5-HT1A receptors releases the serotonergic growth factor, protein $\mathrm{S}-100$, and alters astroglial morphology. Brain Res 528, 155-158.

213. Wilson, C.A., Gonzalez, M.I., Albonetti, M.E., Farabollini, F., 1998. The Involvement of Neonatal 5HT Receptor-Mediated Effects on Sexual Dimorphism of Adult Behavior in the Rat. Males, femalesand behavior. Praeger, Westport, USA, pp. 109-127.

214. Wilson, C.A., Pearson, J.R., Hunter, A.J., Tuohy, P.A., Payne, A.P., 1986. The effect of neonatal manipulation of hypothalamic serotonin levels on sexual activity in the adult rat.

Pharmacol.Biochem.Behav. 24, 1175-1183.

215. Workman, J.L., Gobinath, A.R., Kitay, N.F., Chow, C., Brummelte, S., Galea, L.A., 2016. Parity modifies the effects of fluoxetine and corticosterone on behavior, stress reactivity, and hippocampal neurogenesis. Neuropharmacology 105, 443-453.

216. Xu, Y., Sari, Y., Zhou, F.C., 2004. Selective serotonin reuptake inhibitor disrupts organization of thalamocortical somatosensory barrels during development. Brain Res Dev Brain Res 150, 151-161.

217. Yonkers, K.A., Wisner, K.L., Stewart, D.E., Oberlander, T.F., Dell, D.L., Stotland, N., Ramin, S., Chaudron, L., Lockwood, C., 2009. The management of depression during pregnancy: a report from the American Psychiatric Association and the American College of Obstetricians and Gynecologists. Gen Hosp Psychiatry 31, 403-413.

218. Yoshida, M., Takayanagi, Y., Inoue, K., Kimura, T., Young, L.J., Onaka, T., Nishimori, K., 2009.

Evidence that oxytocin exerts anxiolytic effects via oxytocin receptor expressed in serotonergic neurons in mice. J Neurosci 29, 2259-2271.

219. Yoshimura, R., Kiyama, H., Kimura, T., Araki, T., Maeno, H., Tanizawa, O., Tohyama, M., 1993.

Localization of oxytocin receptor messenger ribonucleic acid in the rat brain. Endocrinology 133, 12391246.

220. Zhao, C., Li, M., 2010. c-Fos identification of neuroanatomical sites associated with haloperidol and clozapine disruption of maternal behavior in the rat. Neuroscience 166, 1043-1055.

221. Zhou, X., Lu, J.Y., Darling, R.D., Simpson, K.L., Zhu, X., Wang, F., Yu, L., Sun, X., Merzenich, M.M., Lin, R.C., 2015. Behavioral training reverses global cortical network dysfunction induced by perinatal antidepressant exposure. Proc Natl Acad Sci U S A 112, 2233-2238.

222. Zimmerberg, B., Germeyan, S.C., 2015. Effects of neonatal fluoxetine exposure on behavior across development in rats selectively bred for an infantile affective trait. Dev Psychobiol 57, 141-152.

223. Zoega, H., Kieler, H., Norgaard, M., Furu, K., Valdimarsdottir, U., Brandt, L., Haglund, B., 2015. Use of SSRI and SNRI Antidepressants during Pregnancy: A Population-Based Study from Denmark, Iceland, Norway and Sweden. PLoS One 10, e0144474.

224. Zohar, I., Dosoretz-Abittan, L., Shoham, S., Weinstock, M., 2014. Sex dependent reduction by prenatal stress of the expression of 5HT1A receptors in the prefrontal cortex and CRF type 2 receptors in the raphe nucleus in rats: reversal by citalopram. Psychopharmacology (Berl). 
Table 1. Summary of individual SRI medications prescribed during the perinatal period to women. ${ }^{1}$ Bakker et al. 2007 (The Netherlands), ${ }^{2}$ Zoega et al. 2015 (Nordic countries), ${ }^{3}$ Oberlander et al. 2008(British Columbia, Canada; \% of total prescriptions in pregnancy women), ${ }^{4}$ Alwan et al. 2011 (United States). Common dose information from www.cms.gov.

\begin{tabular}{|c|c|c|c|c|c|c|}
\hline SRI & Trade Name & $\begin{array}{c}\text { FDA } \\
\text { Rating } \\
\text { During } \\
\text { Pregnancy }\end{array}$ & $\begin{array}{l}\text { Prescription Rate } \\
\text { (\% total pregnancies) }\end{array}$ & $\begin{array}{c}\text { Prescription Rate } \\
\text { (\% total } \\
\text { prescriptions } \\
\text { during pregnancy) }\end{array}$ & $\begin{array}{c}\text { Common Starting Dose } \\
\text { in Adults }\end{array}$ & $\begin{array}{c}\text { Common Maximum Dose } \\
\text { in Adults }\end{array}$ \\
\hline \multicolumn{7}{|c|}{ Selective Serotonin Reuptake Inhibitor (SSRI) } \\
\hline Fluoxetine & Prozac & $\mathrm{C}$ & $\begin{array}{c}0.45^{1} \\
0.22-1.8^{2} \\
1.1^{4}\end{array}$ & $5.2^{3}$ & $20 \mathrm{mg} / \mathrm{day}$ & $80 \mathrm{mg} / \mathrm{day}$ \\
\hline Sertraline & Zoloft & $\mathrm{C}$ & $\begin{array}{c}0.07^{1} \\
0.3-3.32^{2} \\
1.6^{4}\end{array}$ & $4.8^{3}$ & $25 \mathrm{mg} /$ day & 200 mg/day \\
\hline Paroxetine & Paxil & $\mathrm{D}$ & $\begin{array}{c}1.2^{1} \\
0.08-0.59^{2} \\
0.8^{4} \\
\end{array}$ & $8.2^{3}$ & $20 \mathrm{mg} /$ day & $60 \mathrm{mg} /$ day \\
\hline Citalopram & Celexa & $\mathrm{C}$ & $\begin{array}{c}0.18^{1} \\
0.24-1.88^{2} \\
0.2^{4} \\
\end{array}$ & $0.57^{3}$ & $20 \mathrm{mg} /$ day & $40 \mathrm{mg} /$ day \\
\hline Escitalopram & Lexapro & $\mathrm{C}$ & $\begin{array}{c}0.36-1.53^{2} \\
0.2^{4}\end{array}$ & - & $10 \mathrm{mg} /$ day & $20 \mathrm{mg} / \mathrm{day}$ \\
\hline Fluvoxamine & Luvox & $\mathrm{C}$ & $0.26^{1}$ & $0.95^{3}$ & $50 \mathrm{mg} /$ day & $300 \mathrm{mg} /$ day \\
\hline
\end{tabular}

\section{Serotonin Norepinephrine Reuptake Inhibitor (SNRI)}

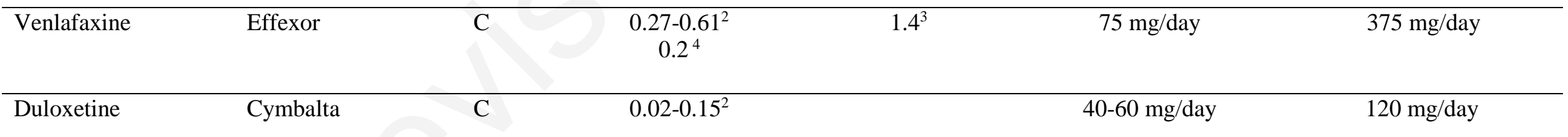

\footnotetext{
${ }^{5}$ https://www.cms.gov/Medicare-Medicaid-Coordination/Fraud-Prevention/Medicaid-Integrity-Education/Pharmacy-Education-Materials/Downloads/ad-adultdosingchart.pdf
} 
Table 2. Summary of laboratory rodent research investigating how perinatal SSRIs affect offspring social behaviors. $P=$ postnatal day, $G=$ gestation day, s.c.=subcutaneous

\begin{tabular}{|c|c|c|c|c|c|c|c|}
\hline $\begin{array}{l}\text { Age } \\
\text { investigated }\end{array}$ & Sex & Species & SSRI (dose/day) & $\begin{array}{l}\text { SSRI } \\
\text { admin }\end{array}$ & Results & Comments & Reference \\
\hline
\end{tabular}

\begin{tabular}{|c|c|c|c|c|c|c|c|}
\hline P28-35, P87 & Male/Female & Wistar rat & $\begin{array}{l}\text { Fluoxetine } \\
(12 \mathrm{mg} / \mathrm{kg})\end{array}$ & G11-P0 & $\begin{array}{l}\text { Fluoxetine reduces pinning, } \\
\text { boxing/wrestling and social exploration } \\
\text { frequency at P28-35. } \\
\text { Fluoxetine reduces self-grooming and } \\
\text { exploration at P87. }\end{array}$ & $\begin{array}{l}\text { Oral injection } \\
\text { to dam. }\end{array}$ & $\begin{array}{l}\text { Olivier et al. } \\
2011\end{array}$ \\
\hline P24-28 & Male/Female & $\begin{array}{l}\text { Long Evans } \\
\text { rat }\end{array}$ & $\begin{array}{l}\text { Citalopram } \\
(20 \mathrm{mg} / \mathrm{kg})\end{array}$ & P8-21 & $\begin{array}{l}\text { Citalopram reduces boxing/wrestling, } \\
\text { following/chasing and exploration } \\
\text { (rearing) and increases self-grooming } \\
\text { (stereotypic behavior). }\end{array}$ & $\begin{array}{l}\text { s.c. injections to } \\
\text { offspring }\end{array}$ & $\begin{array}{l}\text { Khatri et al. } \\
2014\end{array}$ \\
\hline P32-34 & Male/Female & $\begin{array}{l}\text { Long Evans } \\
\text { rat }\end{array}$ & $\begin{array}{l}\text { Citalopram } \\
(10 \mathrm{mg} / \mathrm{kg}) \\
\text { Fluoxetine } \\
(5 \mathrm{mg} / \mathrm{kg})\end{array}$ & P8-21 & $\begin{array}{l}\text { Citalopram reduces male and female } \\
\text { boxing and male pinning while } \\
\text { increasing male stereotypic behaviors. }\end{array}$ & $\begin{array}{l}\text { s.c. injections to } \\
\text { offspring }\end{array}$ & $\begin{array}{l}\text { Rodriguez- } \\
\text { Porcel et al. } \\
2011\end{array}$ \\
\hline P32-34 & Male/Female & $\begin{array}{l}\text { Long Evans } \\
\text { rat }\end{array}$ & $\begin{array}{l}\text { Citalopram } \\
(20 \mathrm{mg} / \mathrm{kg})\end{array}$ & P8-21 & $\begin{array}{l}\text { Citalopram reduces juvenile play in } \\
\text { male, not female, offspring. }\end{array}$ & $\begin{array}{l}\text { s.c. injections to } \\
\text { offspring }\end{array}$ & $\begin{array}{l}\text { Simpson et al, } \\
2011\end{array}$ \\
\hline $\mathrm{P}>56$ & Male & Wistar rat & $\begin{array}{l}\text { Fluoxetine } \\
(20 \mathrm{mg} / \mathrm{kg})\end{array}$ & $\mathrm{P} 0-4$ & $\begin{array}{l}\text { Fluoxetine increases sniffing, contact } \\
\text { behaviors, and total social interaction } \\
\text { time. }\end{array}$ & $\begin{array}{l}\text { s.c. injections to } \\
\text { offspring }\end{array}$ & Ko et al, 2014 \\
\hline \multicolumn{8}{|c|}{ Social Interaction \& Social Preference } \\
\hline $\begin{array}{l}P 30-40 \\
P>60\end{array}$ & Male/Female & $\begin{array}{l}\text { Long Evans } \\
\text { rat }\end{array}$ & $\begin{array}{l}\text { Citalopram } \\
(20 \mathrm{mg} / \mathrm{kg})\end{array}$ & P8-21 & $\begin{array}{l}\text { Citalopram reduces conspecific/object } \\
\text { contacts at } \mathrm{P} 30-40 \text { and } \mathrm{P}>60 \text {. }\end{array}$ & $\begin{array}{l}\text { s.c. injections to } \\
\text { offspring }\end{array}$ & $\begin{array}{l}\text { Simpson et al. } \\
2011\end{array}$ \\
\hline $\begin{array}{l}\text { P78 } \\
\text { P101 }\end{array}$ & Male/Female & $\begin{array}{l}\text { Long Evans } \\
\text { rat }\end{array}$ & $\begin{array}{l}\text { Citalopram } \\
(10 \mathrm{mg} / \mathrm{kg}) \\
\text { Fluoxetine } \\
(5 \mathrm{mg} / \mathrm{kg})\end{array}$ & P8-21 & $\begin{array}{l}\text { Citalopram and fluoxetine reduces male } \\
\text { and female conspecific/object contacts } \\
\text { at P78 and P101. }\end{array}$ & $\begin{array}{l}\text { s.c. injections to } \\
\text { offspring }\end{array}$ & $\begin{array}{l}\text { Rodriguez- } \\
\text { Porcel et al. } \\
2011\end{array}$ \\
\hline
\end{tabular}




\begin{tabular}{|c|c|c|c|c|c|c|c|}
\hline $\begin{array}{l}\mathrm{P} 45 \\
\mathrm{P} 85\end{array}$ & Male/Female & $\begin{array}{l}\text { Long Evans } \\
\text { rat }\end{array}$ & $\begin{array}{l}\text { Citalopram } \\
(20 \mathrm{mg} / \mathrm{kg})\end{array}$ & P8-21 & $\begin{array}{l}\text { Citalopram reduces male and female } \\
\text { conspecific/object contacts at } \mathrm{P} 45 \text { and } \\
85 .\end{array}$ & $\begin{array}{l}\text { s.c. injections to } \\
\text { offspring }\end{array}$ & $\begin{array}{l}\text { Khatri et al. } \\
2014\end{array}$ \\
\hline $\begin{array}{l}\text { P34 } \\
\text { P76 }\end{array}$ & Male/Female & $\begin{array}{l}\text { Norway } \\
\text { High/Low } \\
\text { lines }\end{array}$ & $\begin{array}{l}\text { Fluoxetine } \\
(10 \mathrm{mg} / \mathrm{kg})\end{array}$ & P2-7 & $\begin{array}{l}\text { Fluoxetine reduces time spent with a } \\
\text { novel conspecific at P34 and } 76 \text {. }\end{array}$ & $\begin{array}{l}\text { Oral gavage to } \\
\text { offspring }\end{array}$ & $\begin{array}{l}\text { Zimmerberg } \\
\text { et al. } 2015\end{array}$ \\
\hline $\begin{array}{l}\text { P28-31 } \\
\text { P49-52 }\end{array}$ & Male/Female & $\begin{array}{l}\text { ICR (CD1) } \\
\text { mice }\end{array}$ & $\begin{array}{l}\text { Fluoxetine } \\
(10 \mathrm{mg} / \mathrm{kg})\end{array}$ & G1-P0 & $\begin{array}{l}\text { Adult animals spend more time with } \\
\text { social conspecific, particularly males. } \\
\text { Fluoxetine increases female conspecific } \\
\text { interaction at P28-31. } \\
\text { Fluoxetine increases number and } \\
\text { duration of aggressive attacks in males } \\
\text { at P49-52. }\end{array}$ & $\begin{array}{l}\text { s.c. injections to } \\
\text { dams }\end{array}$ & $\begin{array}{l}\text { Svirsky et al. } \\
2016\end{array}$ \\
\hline $\mathrm{P}>60$ & Male & $\begin{array}{l}\mathrm{C} 57 \mathrm{BL} / 6 \\
\text { mice }\end{array}$ & $\begin{array}{l}\text { Fluoxetine } \\
(25 \mathrm{mg} / \mathrm{kg})\end{array}$ & G15-P12 & $\begin{array}{l}\text { Fluoxetine increases aggressive attacks } \\
\text { and time spent in aggressive behaviors. } \\
\text { Fluoxetine did not affect time spent in } \\
\text { social behavior with a resident intruder. }\end{array}$ & $\begin{array}{l}\text { Administration } \\
\text { via drinking } \\
\text { water to dams. }\end{array}$ & $\begin{array}{l}\text { Kiryanova et } \\
\text { al. } 2014\end{array}$ \\
\hline P90-120 & Males & Wistar rat & $\begin{array}{l}\text { Citalopram } \\
(20 \mathrm{mg} / \mathrm{kg} / 3 \text { days })\end{array}$ & P1-19 & $\begin{array}{l}\text { Citalopram reduces duration of } \\
\text { aggressive attacks on a resident intruder. }\end{array}$ & $\begin{array}{l}\text { s.c. injections to } \\
\text { offspring }\end{array}$ & $\begin{array}{l}\text { Manhaes de } \\
\text { Castro et al. } \\
2001\end{array}$ \\
\hline
\end{tabular}

\begin{tabular}{|c|c|c|c|c|c|c|c|}
\hline \multicolumn{8}{|c|}{ Reproductive Behavior } \\
\hline P103-111 & Female & $\begin{array}{l}\text { Sprague- } \\
\text { Dawley rat }\end{array}$ & $\begin{array}{l}\text { Fluoxetine } \\
(5 \mathrm{mg} / \mathrm{kg})\end{array}$ & $\mathrm{P} 1-21$ & $\begin{array}{l}\text { Fluoxetine facilitates sexual behaviors, } \\
\text { regardless of maternal stress exposure, } \\
\text { and does not affect SDN-POA, ACPv } \\
\text { and pBST brain areas, or estrous } \\
\text { cyclicity. }\end{array}$ & $\begin{array}{l}\text { Osmotic } \\
\text { minipump to } \\
\text { the dam; model } \\
\text { of maternal } \\
\text { stress }\end{array}$ & $\begin{array}{l}\text { Rayen et al. } \\
2014\end{array}$ \\
\hline P80-88 & Male & $\begin{array}{l}\text { Sprague- } \\
\text { Dawley rat }\end{array}$ & $\begin{array}{l}\text { Fluoxetine } \\
(5 \mathrm{mg} / \mathrm{kg})\end{array}$ & P1-21 & $\begin{array}{l}\text { Fluoxetine exposure inhibits sexual } \\
\text { behavior. } \\
\text { Fluoxetine after maternal stress } \\
\text { decreases the area of the SDN-POA. }\end{array}$ & $\begin{array}{l}\text { Osmotic } \\
\text { minipump to } \\
\text { the dam; model } \\
\text { of maternal } \\
\text { stress }\end{array}$ & $\begin{array}{l}\text { Rayen et al. } \\
2013\end{array}$ \\
\hline $\mathrm{P}>100$ & Male & $\begin{array}{l}\text { Long Evans } \\
\text { rat }\end{array}$ & $\begin{array}{l}\text { Citalopram }(5, \\
10 \text { or } 20 \mathrm{mg} / \mathrm{kg})\end{array}$ & P8-21 & $\begin{array}{l}\text { Citalopram exposure results in dose- } \\
\text { dependent reductions mounting, }\end{array}$ & $\begin{array}{l}\text { s.c. injections to } \\
\text { offspring }\end{array}$ & $\begin{array}{l}\text { Harris et al. } \\
2012\end{array}$ \\
\hline
\end{tabular}




\begin{tabular}{|c|c|c|c|c|c|c|c|}
\hline P133 & Male & Wistar rat & $\begin{array}{l}\text { Fluoxetine } \\
(12 \mathrm{mg} / \mathrm{kg})\end{array}$ & G11-21 & $\begin{array}{l}\text { Fluoxetine does not affect male sexual } \\
\text { behavior }\end{array}$ & $\begin{array}{l}\text { S.c. injections to } \\
\text { dam }\end{array}$ & $\begin{array}{l}\text { Oliver et al. } \\
2011\end{array}$ \\
\hline P153-184 & Male & $\begin{array}{l}\text { Long Evans } \\
\text { rat }\end{array}$ & $\begin{array}{l}\text { Fluoxetine } \\
(5 \mathrm{mg} / \mathrm{kg})\end{array}$ & P8-21 & $\begin{array}{l}\text { Fluoxetine disrupts male sexual } \\
\text { behavior: fewer mounts, intromissions } \\
\text { and ejaculations }\end{array}$ & $\begin{array}{l}\text { s.c. injections to } \\
\text { offspring }\end{array}$ & $\begin{array}{l}\text { Rodriguez } \\
\text { Porcel et al. } \\
2011\end{array}$ \\
\hline P80 & Male & Wistar rat & $\begin{array}{l}\text { Fluoxetine }(5 \\
\text { and } 10 \mathrm{mg} / \mathrm{kg})\end{array}$ & G13-20 & $\begin{array}{l}\text { Fluoxetine has no effect on male sex } \\
\text { behavior }\end{array}$ & $\begin{array}{l}\text { s.c. injections to } \\
\text { dam }\end{array}$ & $\begin{array}{l}\text { Cagliano et al. } \\
2008\end{array}$ \\
\hline $\mathrm{P}>90$ & Male & Swiss mice & $\begin{array}{l}\text { Fluoxetine } \\
(7.5 \mathrm{mg} / \mathrm{kg})\end{array}$ & G0-P21 & Fluoxetine impairs sexual motivation & $\begin{array}{l}\text { Oral gavage to } \\
\text { dam }\end{array}$ & $\begin{array}{l}\text { Gouvea et al. } \\
2008\end{array}$ \\
\hline $\mathrm{P} 90$ & Male & $\begin{array}{l}\text { Long Evans } \\
\text { rat }\end{array}$ & $\begin{array}{l}\text { Citalopram } \\
(5 \mathrm{mg} / \mathrm{kg})\end{array}$ & P8-21 & $\begin{array}{l}\text { Citalopram decreases sexual activity: } \\
\text { fewer mounts, intromissions and } \\
\text { ejaculations }\end{array}$ & $\begin{array}{l}\text { s.c. injections to } \\
\text { offspring }\end{array}$ & $\begin{array}{l}\text { Maciag et al. } \\
2006\end{array}$ \\
\hline \multicolumn{8}{|c|}{ Maternal Behavior } \\
\hline $\mathrm{P}>60$ & Female (F1) & $\begin{array}{l}\mathrm{ICR}(\mathrm{CD} 1) \\
\text { mice }\end{array}$ & $\begin{array}{l}\text { Fluoxetine } \\
(10 \mathrm{mg} / \mathrm{kg})\end{array}$ & G1-P0 & $\begin{array}{l}\text { Fluoxetine reduces maternal behavior } \\
\text { on PD1 via reduced nest quality and } \\
\text { delayed pup retrieval. Fluoxetine } \\
\text { exposed females showed more } \\
\text { adaptability in maternal behaviors, with } \\
\text { greater improvements in maternal care } \\
\text { on PD } 2 \text { and } 3 .\end{array}$ & $\begin{array}{l}\text { s.c. injections to } \\
\text { dams (F0) }\end{array}$ & $\begin{array}{l}\text { Svirsky et al. } \\
2016\end{array}$ \\
\hline
\end{tabular}


$\underline{\text { Highlights }}$

- Serotonin and SSRIs are mediators of maternal care-giving behaviors

- Perinatal SSRIs affect development of play, social, and reproductive behaviors

- Perinatal SSRIs and maternal stress alter the developing serotonergic system

- Perinatal SSRIs alter neuroplasticity and epigenetic profiles in offspring 